OPEN ACCESS

Edited by:

Juan B. Barroso,

University of Jaén, Spain

Reviewed by:

Youry Pii,

Free University of Bozen-Bolzano, Italy Masayuki Fujita,

Kagawa University, Japan

*Correspondence:

Asim Masood

asim.bot@gmail.com

Specialty section:

This article was submitted to

Plant Physiology,

a section of the journal

Frontiers in Plant Science

Received: 07 October 2019

Accepted: 29 April 2020

Published: 29 May 2020

Citation:

Rather BA, Masood A, Sehar Z, Majid A, Anjum NA and Khan NA (2020) Mechanisms and Role of Nitric

Oxide in Phytotoxicity-Mitigation

of Copper. Front. Plant Sci. 11:675.

doi: 10.3389/fp/s.2020.00675

\section{Mechanisms and Role of Nitric Oxide in Phytotoxicity-Mitigation of Copper}

\author{
Bilal A. Rather, Asim Masood*, Zebus Sehar, Arif Majid, Naser A. Anjum and \\ Nafees A. Khan
}

Plant Physiology and Biochemistry Laboratory, Department of Botany, Aligarh Muslim University, Aligarh, India

Phytotoxicity of metals significantly contributes to the major loss in agricultural productivity. Among all the metals, copper (Cu) is one of essential metals, where it exhibits toxicity only at its supra-optimal level. Elevated $\mathrm{Cu}$ levels affect plants developmental processes from initiation of seed germination to the senescence, photosynthetic functions, growth and productivity. The use of plant growth regulators/phytohormones and other signaling molecules is one of major approaches for reversing Cu-toxicity in plants. Nitric oxide (NO) is a versatile and bioactive gaseous signaling molecule, involved in major physiological and molecular processes in plants. NO modulates responses of plants grown under optimal conditions or to multiple stress factors including elevated $\mathrm{Cu}$ levels. The available literature in this context is centered mainly on the role of $\mathrm{NO}$ in combating $\mathrm{Cu}$ stress with partial discussion on underlying mechanisms. Considering the recent reports, this paper: (a) overviews $\mathrm{Cu}$ uptake and transport; (b) highlights the major aspects of Cu-toxicity on germination, photosynthesis, growth, phenotypic changes and nutrient-use-efficiency; (c) updates on NO as a major signaling molecule; and (d) critically appraises the Cu-significance and mechanisms underlying NO-mediated alleviation of Cu-phytotoxicity. The outcome of the discussion may provide important clues for future research on NO-mediated mitigation of Cu-phytotoxicity.

Keywords: copper, nitric oxide, oxidative stress, photosynthesis, Cu-stress mitigation

\section{INTRODUCTION}

The increasing industrialization, hasty urbanization together with excessive use of chemical fertilizers and sewage sludge/water led to the severe contamination of soils with varied metals and metalloids (Nagajyoti et al., 2010; Brunetto et al., 2016; Asgher et al., 2018a,b). Among metals, copper $(\mathrm{Cu})$ is an essential metal for plants, and promotes therein growth and development at $9.0 \mathrm{mg} \mathrm{kg}{ }^{-1}$ (Havlin et al., 1999). The average content of $\mathrm{Cu}$ in plant tissues is $10 \mu \mathrm{g} \mathrm{g}^{-1} \mathrm{dry}$ weight; whereas, the precarious $\mathrm{Cu}$ concentration in nutrient media ranges between $10^{-14}$ and $10^{-16} \mathrm{M}$ at which its deficiency has been noted (Baker and Senef, 1995). Cu is involved in the photosynthetic electron transport and redox reactions and it also acts as a cofactor in $\mathrm{Cu} / \mathrm{Zn}$ superoxide dismutase (Cu/Zn-SOD) (Bowler et al., 1994; Ouzounidou et al., 1995; Raven et al., 1999; Adrees et al., 2015). However, elevated $\mathrm{Cu}$ concentration can induce oxidative stress mainly through increased generation of reactive oxygen species (ROS) and thereby inhibit plant growth and productivity (Piotrowska-Niczyporuk et al., 2012; Thounaojam et al., 2012; Adrees et al., 2015; Chen et al., 2015). 
Plants adopt different strategies to overcome elevated $\mathrm{Cu}$ concentration-caused toxicity. The list of these strategies includes the increased nutrient assimilation, induction in the antioxidant defense system, and the activation of biochemical and physiological processes such as increased signaling through associated plant growth regulators (PGRs). PGRs such as auxins (AUXs), cytokinins (CKs), gibberellins (GAs), brassinosteroids (BRs), ethylene (ET), jasmonic acids (JA), polyamines (PA), salicylic acid (SA), nitric oxide (NO), and strigolactones modulate physiological/biochemical and genetic processes and improve plant tolerance to major abiotic stresses including metals/metalloids (Maksymiec et al., 2007; Meng et al., 2009; Khan et al., 2012, 2015, 2016; Masood et al., 2012, 2016; Per et al., 2016, 2017a; Asgher et al., 2018a,b).

Earlier known as a vital signaling and effector molecule in animals, NO is known to occur also in plants, and act therein as a short-lived multifunctional gaseous signaling molecule (Astier et al., 2017). NO controls overall plant growth and the developmental processes starting from germination to senescence (Hu et al., 2007; Corpas and Barroso, 2015b). In particular, recent studies have shown that both production and signaling of $\mathrm{NO}$ are involved in the stress-acclimation processes in plants (Khan et al., 2012; Asgher et al., 2017; Kushwaha et al., 2019; Santisree et al., 2019). However, literature available in context with $\mathrm{NO}$ and plants is centered mainly on NO synthesis and its multitasking signaling in plants (Domingos et al., 2015; Astier et al., 2017). Additionally, literature in this context also reflected the role of exogenously applied NO in combating $\mathrm{Cu}$ stress with partial discussion on underlying potential mechanisms (Khan et al., 2012).

Given above, this paper is aimed to: (i) overview the aspects of the uptake, transport, and role of $\mathrm{Cu}$ in photosynthesis and nutrient-use-efficiency; (ii) highlight major aspects of $\mathrm{Cu}$ phytotoxicity; (iii) discuss $\mathrm{NO}$ as a signaling molecule; and (iv) critically appraise the $\mathrm{Cu}$-significance and mechanisms underlying $\mathrm{NO}$-mediated alleviation $\mathrm{Cu}$-toxicity in plants. Important clues for future research in this direction with the outcome of the facts are also discussed herein.

\section{COPPER IN HIGHER PLANTS}

Copper $(\mathrm{Cu})$ is an essential trace element of most living organisms on the earth including plants, where $>30$ types of proteins are known to possess $\mathrm{Cu}$ as their structural constituent (Cohu and Pilon, 2010; Anjum et al., 2015b). As an essential micronutrient for plants, a minimum amount of $\mathrm{Cu}$ ensures different cellular functions. However, an excess uptake of $\mathrm{Cu}$ in plants may cause detrimental effects in metabolic functions and even risk to their survival (Adrees et al., 2015; Ambrosini et al., 2018; Marastoni et al., 2019b). In plants, $\mathrm{Cu}$ exists in two common oxidation states namely, $\mathrm{Cu}^{2+}$ and $\mathrm{Cu}^{+}$ions. $\mathrm{Cu}^{2+}$ frequently prefers coordination with oxygen in aspartic and glutamic acid and with nitrogen in histidine side chains. On the other, $\mathrm{Cu}^{+}$has a higher affinity with the sulfur in methionine or cysteine. The list of major $\mathrm{Cu}$-containing proteins in plants includes plastocyanin, cytochrome-c oxidase (COX), ethylene receptors, $\mathrm{Cu} / \mathrm{Zn}$-superoxide dismutase ( $\mathrm{Cu} / \mathrm{Zn} \mathrm{SOD})$, tyrosinase, plantacyanin, phenol oxidase, laccase, ascorbate, and amine oxidase (Table 1). Cu mainly contributes in the transport of electrons in chloroplasts and mitochondria. Plastocyanin is one of the most abundant $\mathrm{Cu}$ proteins in photosynthetic tissues (Weigel et al., 2003). It is located in thylakoid lumen of chloroplasts and is responsible for the transport of electrons from cytochrome b6f complex to $\mathrm{P} 700^{+}$. Though in some algae this function can be served by a heme-containing cytochrome c6, information is scanty on the ortholog that can mimic the same function of plastocyanin in higher plants (Schubert et al., 2002; Wise and Hoober, 2007). $\mathrm{Cu}$ also serves as a critical co-factor in the mitochondria as a respiratory chain enzyme cytochrome $c$ oxidase (COX). Composed of 12-14 sub-units, plant COX is the terminal enzymatic complex IV of the mitochondrial respiratory chain (Millar et al., 2004). Another major Cu-binding protein in plants is $\mathrm{Cu} / \mathrm{Zn}$-superoxide dismutase $(\mathrm{Cu} / \mathrm{Zn}-\mathrm{SOD})$ that occurs in cytosol, chloroplasts, and peroxisomes. Arabidopsis possess three isoforms of CuZn-SOD, where CSD1 is located in the cytoplasm; CSD2 in chloroplast stroma, and CSD3 is a peroxisomal isoform having a minor activity (Kliebenstein et al., 1998). Another Cu-protein plantacyanin belongs to phytocyanin family of blue $\mathrm{Cu}$ containing proteins. Based on their magnetic and spectroscopic properties, plantacyanins are classified as Type I Cu proteins with size about 10-22 kDa (de Rienzo et al., 2000), and are primarily present in the cell wall. They are believed to act as transporters of electrons between a donor and acceptor. Plantacyanins are expressed in plants exposed to stresses such as high/low temperature, heavy metals, and high salinity, and are involved in plant-tolerance to these stresses (Maunoury and Vaucheret, 2011; Feng et al., 2013). Cu-dependent protein laccase belongs to the large group of multi-copper oxidases (MCOs) and is involved in polymerization (McCaig et al., 2005; Printz et al., 2016). Cu-dependent amine oxidases (CuAO) are among the amine oxidases and are associated with the cell wall, and flavin-containing polyamine oxidases. In plants, $\mathrm{CuAO}$ catalyzes the oxidation of putrescine that produces $\mathrm{H}_{2} \mathrm{O}_{2}$ involved in cell wall maturation, lignification, and programmed cell death (Cona et al., 2006). Polyphenol oxidase and ascorbate oxidases (AO) also belong to $\mathrm{Cu}$-containing MCOs. Localized in the apoplast, AOs oxidize ascorbate into water and monodehydroascorbate, and thereby regulate its redox state (Kaur and Nayyar, 2014). AOs also modulate cell division and cell expansion via L-ascorbic acid (L-AA) redox repair (Kerk and Feldman, 1995; Kato and Esaka, 1999). Polyphenol oxidases are found in thylakoids, where these are involved in the defense mechanisms against pests and pathogens (Constabel and Barbehenn, 2008). In addition, $\mathrm{Cu}$ also plays an important role in cell signaling as the part of receptor proteins for ethylene sensing (Rodriguez et al., 1999). $\mathrm{Cu}$-homeostasis is mainly regulated by the transcription factor SQUAMOSA PROMOTER BINDING PROTEIN-LIKE7 (SPL7). Through activating the transcription of plasma membrane COPT transporter genes (COPT1, COPT2, and COPT6), SPL7 modulates the $\mathrm{Cu}$-uptake and homeostasis under $\mathrm{Cu}$-deficiency (Yamasaki et al., 2009; Bernal et al., 2012). Thus, these requirements make $\mathrm{Cu}$ an ideal metal for normal functioning, growth and development in plants. 
TABLE 1 | Summary of copper-associated proteins and their functions in plants. ${ }^{1}$

\begin{tabular}{|c|c|c|}
\hline Type & Protein & Function \\
\hline \multicolumn{3}{|c|}{ Cell Surface/Secretory Compartment } \\
\hline \multicolumn{3}{|c|}{ Transporters and Receptors } \\
\hline & P1B-Type ATPases & Proteins concerned with export of $\mathrm{Cu}^{+}$ \\
\hline & Ctr (copper transporter) & Proteins involved in import of $\mathrm{Cu}^{+}$ \\
\hline & Ethylene receptor & Cu acts as a cofactor and activates ethylene signaling \\
\hline \multicolumn{3}{|c|}{ Electron transfer/Blue Cu proteins } \\
\hline & Cytochrome $c$ oxidase & Plays an important role in the last step of respiration \\
\hline & Plastocyanin & Electron transfer during photosynthesis \\
\hline \multicolumn{3}{|c|}{ Free Radical Scavenging } \\
\hline & $\mathrm{Cu} / \mathrm{Zn} \mathrm{SOD}$ & Scavenger of free radicals \\
\hline \multicolumn{3}{|c|}{ Oxidase } \\
\hline & Laccase & Oxidative de-amination of polyamines \\
\hline & Ascorbate oxidase & Regulates redox state of the cell \\
\hline & Amine oxidase & Involved in cell wall maturation, lignification, Oxidizes diamines \\
\hline & Polyphenol oxidase & $\begin{array}{l}\text { Plays an important role in defensive mechanisms against pests } \\
\text { and pathogens }\end{array}$ \\
\hline \multicolumn{3}{|c|}{ Transcriptional regulators } \\
\hline & Spl7 & $\begin{array}{l}\text { Transcriptional activator which gets activated in response to } \\
\text { reduced Cu levels. }\end{array}$ \\
\hline \multicolumn{3}{|c|}{ Chaperons/Storage } \\
\hline & Atx1 (Antioxidant protein 1) & A metal chaperone carrying Cu to P-Type ATPases \\
\hline & Ccs (Cu chaperone for superoxide dismutase) & Transports Cu to Cu/Zn SOD1 \\
\hline
\end{tabular}

${ }^{1}$ Based on the literature appraised in the paper.

On the contrary, the condition of both $\mathrm{Cu}$-deficiency and -elevation can bring severe consequences in plants (Yruela, 2005). Plants produced under Cu-deficiency showed alteration in the photosynthetic transport chain and reduction in the nonphotochemical quenching, which is mainly due to inhibition in the function of plastocyanin (Abdel-Ghany and Pilon, 2008). On the otherside, $\mathrm{Cu}$ in excess causes significant toxicity and even the arrest of cellular metabolism in plants. In particular, photosynthetic electron transport is the main target under both $\mathrm{Cu}$-deficiency and as well as in excess $\mathrm{Cu}$. Therefore, it is essential to ensure adequate $\mathrm{Cu}$-uptake and distribution in order to minimize its deleterious phytotoxic effects that in turn would regulate various homeostatic processes at cellular and whole plant levels.

\section{COPPER UPTAKE AND TRANSPORT}

Higher plants mainly take $\mathrm{Cu}$ in the form of $\mathrm{Cu}^{2+}$ ions from the rhizosphere, where the binding of $\mathrm{Cu}$ with various ligands facilitates the process (Welch et al., 1993). The studies on $\mathrm{Cu}$ uptake and transport into or within the cells are still in infancy. However, the successful implementation of advanced tools helped in uncovering transport process in yeast and other eukaryotic organisms (Nelson, 1999; Nevitt et al., 2012). Maintenance or correct regulation of $\mathrm{Cu}$-homeostasis under $\mathrm{Cu}$-regimes is governed by a complex system of metal-trafficking pathways available in higher plants. Plants possess a number of $\mathrm{Cu}$ transporters (COPT; COPT1-6) involved in the uptake of $\mathrm{Cu}$ and secretion of metal ions (Puig et al., 2007; Andrés-Bordería et al., 2017; Andrés-Colás et al., 2018).
Current understandings on COPTs came into light as a result of having sequence homology with the eukaryotic $\mathrm{Cu}$ transporters (named Ctr) and functional complementation in yeast (Puig and Thiele, 2002; Puig et al., 2007; Puig, 2014; AndrésBordería et al., 2017). All the members of this family contain three predicted transmembrane (TM) segments. The majority of the COPTs exhibit N-terminus methionine and histidine-rich putative metal-binding domains (Puig and Thiele, 2002; Klomp et al., 2003). In Arabidopsis genome, there occurs six COPT genes (COPT 1-6) encoding COPT transporters. COPT1, one of the most characterized members of the $\mathrm{Cu}$-transporter family has been reported to permit the entry of $\mathrm{Cu}$ into the cells from outside to the cytoplasm (Kampfenkel et al., 1995; Sancenón et al., 2003). In addition, owing to its low Michaelis constant (KM) value, COPT1 transporter has also been reported to exhibit its high specificity for $\mathrm{Cu}^{2+}$ ion (Eisses and Kaplan, 2002; Sancenón et al., 2003). High specificity toward $\mathrm{Cu}^{2+}$ ions has also been reported for COPT2 and COPT 6 transporters (Jung et al., 2012; Garcia-Molina et al., 2013; Perea-García et al., 2013; Aguirre and Pilon, 2016). Potentially involved in the intracellular transport of $\mathrm{Cu}, \mathrm{COPT} 3$ and COPT5 transporters possess one each of methionine and a histidine-rich box. Methionine residues and motifs vital for Ctr1 mediated high-affinity Cu-transport do not occur in COPT4 that has a non-direct role in $\mathrm{Cu}$-transportation (Sancenón et al., 2004).

In addition to other processes, the transport of $\mathrm{Cu}^{2+}$ across the plasma membranes also involves P-type heavy metal ATPases (Williams and Mills, 2005; Takahashi et al., 2012; Yan et al., 2016). The transport of $\mathrm{Cu}$ into the cells may also be ascertained by the newly found cytosolic, soluble and low molecular weight heavy metal receptor proteins such as $\mathrm{Cu}$ chaperones $(\mathrm{CCH})$, known 
as metallo-chaperones (O'Halloran and Culotta, 2000; Huffman and O'Halloran, 2001). Cu chaperones including COX17 (Cu chaperone for COX), CCS ( $\mathrm{Cu}$ chaperone for SOD), and two homologs of the yeast ATX1 (antioxidant protein 1) and $\mathrm{CCH}$ (ATX1-like $\mathrm{Cu}$ chaperone) were reported to be involved in the intracellular $\mathrm{Cu}$ transport in Arabidopsis (Casareno et al., 1998; Chu et al., 2005; Puig et al., 2007). The knowledge regarding the transport of $\mathrm{Cu}$ into the xylem is still in its infancy. In a recent study, compared to roots developed on different metal ions the roots developed on media with $50 \mu \mathrm{M} \mathrm{Cu}$ exhibited a huge decline in the levels of callose (O'Lexy et al., 2018). Additionally, $\mathrm{Cu}$ was observed to move through plasmodesmata by influencing plasmodesmata via regulating $\beta$-1,3-glucanases.

\section{COPPER-INDUCED TOXICITY IN PLANTS}

A large volume of literature is available on the impact of elevated $\mathrm{Cu}$ on major aspects in plants including germination and growth (López-Bucio et al., 2003; Lin et al., 2005; Mench and Bes, 2009; Potters et al., 2009; Bouazizi et al., 2010; Lequeux et al., 2010; Verma et al., 2011; Feigl et al., 2013; Gang et al., 2013; Muccifora and Bellani, 2013; Adrees et al., 2015; Marques et al., 2018), photosynthesis and related variables (Chatterjee and Chatterjee, 2000; Quartacci et al., 2000; Yruela, 2005; Küpper et al., 2009; Gonzalez-Mendoza et al., 2013; Mateos-Naranjo et al., 2013; Adrees et al., 2015; Feigl et al., 2015; de Freitas et al., 2015; Emamverdian et al., 2015; Sharma et al., 2017; Ambrosini et al., 2018), phenotypic changes (Barbosa et al., 2013; Feigl et al., 2013; Sánchez-Pardo et al., 2014; Adrees et al., 2015; Nair and Chung, 2015; Ali et al., 2016; Brunetto et al., 2016; Llagostera et al., 2016; Mwamba et al., 2016; Ambrosini et al., 2018; Shiyab, 2018; Marastoni et al., 2019b; Nazir et al., 2019; Shams et al., 2019), and nutrient-use-efficiency of plants (Chatterjee and Chatterjee, 2000; Ali et al., 2002; Keutgen and Pawelzik, 2008; Ivanova et al., 2010; Feigl et al., 2013; Azeez et al., 2015; Bankaji et al., 2015; Marastoni et al., 2019a). A brief discussion on the $\mathrm{Cu}$-induced changes in germination and growth, photosynthesis and related variables, phenotypic changes, and nutrient-use-efficiency of plants are presented hereunder.

\section{Germination and Growth}

The effect of $\mathrm{Cu}$ was seen at different growth and developmental stages of plants from seed germination to the senescence. Contingent to $\mathrm{Cu}$ level and the growth stage of the test plant, excess $\mathrm{Cu}$ significantly affects $\mathrm{Cu}$-sensitive plants. In germinating seeds, increasing $\mathrm{Cu}$ concentrations reduced the germination percentage of seeds in different plant species (Gang et al., 2013; Muccifora and Bellani, 2013). Similarly, germination in mungbean seeds was reported to decrease with increasing $\mathrm{Cu}$ concentrations (Verma et al., 2011). During an early stage of growth, elevated $\mathrm{Cu}$ concentrations inhibited leaf expansion but increased pigment content (Maksymiec et al., 1994; Maksymiec and Baszyński, 1996; Adrees et al., 2015). In addition to inhibition in growth and biomass, $\mathrm{Cu}$ toxicity in plants also includes bronzing/necrosis (Marschner, 1995; Mench and Bes,
2009; Marques et al., 2018). Increasing Cu-concentration reduces uptake of Fe, Zn, Mn, and Co (Marschner, 1995; Bouazizi et al., 2010; Feigl et al., 2013). Significant reductions in root and shoot biomass were found in Arabidopsis exposed to 2.5 and $5 \mu \mathrm{M} \mathrm{Cu}$ for 14 days (Lequeux et al., 2010). Elevated Cu can inhibit primary root growth and simultaneously stimulate lateral root formation and thereby remodel the root structure (López-Bucio et al., 2003; Potters et al., 2009; Lequeux et al., 2010). Excess $\mathrm{Cu}$ also causes overproduction of $\mathrm{H}_{2} \mathrm{O}_{2}$, which eventually weakens the cell wallextensibility (Lin et al., 2005). Root growth is more severely affected by increased $\mathrm{Cu}$ than shoot growth that is obvious due to the retention of the major proportion of $\mathrm{Cu}$ taken up by plants.

\section{Photosynthesis and Related Variables}

Impacts of $\mathrm{Cu}$ on photosynthesis are well documented. The photosynthetic apparatus is susceptible to heavy metal toxicity, which in turn directly or indirectly significantly impact photosynthetic functions. Excess $\mathrm{Cu}$ has been reported to decrease the level of photosynthetic pigments such as chlorophyll (Küpper et al., 2009; Ambrosini et al., 2018). Cu concentrations were reported to decrease chlorophyll content in a number of plants including spinach (Ouzounidou et al., 1998), maize (Mocquot et al., 1996), cauliflower (Chatterjee and Chatterjee, 2000), and rapeseed and Indian mustard plants (Feigl et al., 2015). Cu excess can also impair chloroplast structure and thylakoid membrane composition (de Freitas et al., 2015; Sharma et al., 2017). Ciscato et al. (1997) found that the reduction in chlorophyll biosynthesis was mainly due to $\mathrm{Cu}$ exposure mediated structural damages of chloroplast particularly at the thylakoid level. Disturbed metabolic activities like loss of chloroplast integrity, and change in plastid membrane composition and inhibition of photosynthetic electron transport have also been evidenced in plants exposed to elevated $\mathrm{Cu}$ levels (Quartacci et al., 2000; Adrees et al., 2015). Cu was found to inhibit both PS I and PS II, where PS II was found very sensitive to elevated $\mathrm{Cu}$ (Yruela, 2005). In another study, excess of $\mathrm{Cu}$ caused a reduction in photosynthesis mainly as a consequence of the higher photoinhibition (Mateos-Naranjo et al., 2013; Adrees et al., 2015). Cu in excess may also block the photosynthetic electron transport, inhibit photophosphorylation, and decrease membrane integrity (Maksymiec et al., 1994; Emamverdian et al., 2015). Cu-excess blocked the flow of electrons from Tyr $\mathrm{z}$ to $\mathrm{P}_{680}{ }^{+}$(Yruela, 2005). In Avicennia germinans elevated Cumediated $100 \%$ inhibition of net photosynthesis and reduction of chlorophyll fluorescence with damaged photosynthetic apparatus (Gonzalez-Mendoza et al., 2013). In a recent study on fibrous jute (Corchorus capsularis) plants, Saleem et al. (2020) reported heavy damage in the organelles of the leaves by exposure to soils having $\mathrm{Cu}$-contaminated soil mixed with natural soil by 1:4 ratio. The authors also found a large number of chloroplast particles accumulated inside the cell wall and also outside the chloroplast in these plants.

\section{Phenotypic Changes}

Surplus level of $\mathrm{Cu}$ restricts plant growth and development (Shams et al., 2019). The impact of Cu toxicity is primarily on root growth and phenotype, which has a paramount significance 
to the whole plant. In general, $\mathrm{Cu}$ accumulates mainly in roots rather than in shoots, although the different distribution and translocation of $\mathrm{Cu}$ depends on its concentration in the rootgrowing medium (Adrees et al., 2015). However, both shoots and roots exhibit specific symptoms of $\mathrm{Cu}$-toxicity. High $\mathrm{Cu}$ concentrations in shoots induced pale green to white interveinal chlorosis on mature leaves, altered membrane permeability, enzyme activities and also reduced photosynthesis (Brunetto et al., 2016). In roots, excess $\mathrm{Cu}$ reduces root length and leads to darkening and thickening of root tips (Feigl et al., 2013). $\mathrm{Cu}$ stress has also been reported to decrease the area and expansions of leaves, and the size of stem in several plants (Barbosa et al., 2013; Feigl et al., 2013). In addition to reductions in shoot and root growth, elevated $\mathrm{Cu}$-exposed plants exhibited phenotypic changes as toxicity symptoms, where roots showed intense dark color with increasing $\mathrm{Cu}$ concentration (Marastoni et al., 2019b). In several studies, elevated acquisition of $\mathrm{Cu}$ was culminated into chlorosis, leaf epinasty, decreased branching, thickening, and dark coloration (Nair and Chung, 2015; Ali et al., 2016) and also to the development of necrotic patches in leaf tips and margins (Llagostera et al., 2016). Altered surface root morphology, rolling of the leaf blade and reduced leaf area were also reported in plants under elevated $\mathrm{Cu}$-exposure (SánchezPardo et al., 2014; Nazir et al., 2019). Phytotoxic concentrations of $\mathrm{Cu}$ also impede the leaf proliferation, cell elasticity, and cell division and reduced the number and abundance of intercellular spaces and densely developed dark colored areas of xylem vessels (Ambrosini et al., 2018; Shiyab, 2018). Elevated Cuaccrued reduction in the leaf area resulted in reduced dry matter production (Mwamba et al., 2016). Therefore, phenotypic attributes may function as an effective bioindicator of $\mathrm{Cu}$ toxicity as well as for the characterization of the plants as resilient or sensitive to excess $\mathrm{Cu}$.

\section{Nutrient-Use-Efficiency of Plants}

The accumulation of ions such as $\mathrm{Na}^{+}$and $\mathrm{Cl}^{-}$accumulated in plant organs may compete with mineral nutrients and also disturb their uptake, translocation, and assimilation (Keutgen and Pawelzik, 2008). Higher concentrations of $\mathrm{Cu}$ reduced the content of $\mathrm{N}, \mathrm{P}$, and $\mathrm{K}$ in both shoot and root of maize; however, increased therein the concentration of Fe (Ali et al., 2002; Azeez et al., 2015). In sand culture grown cauliflower, the supply of $0.5 \mathrm{mM} \mathrm{Cu}$ for 30 days decreased Fe concentration (Chatterjee and Chatterjee, 2000). In both leaves and roots of Brassica juncea and $B$. napus, excess $\mathrm{Cu}$ impacted microelement homeostasis and decreased the concentrations of $\mathrm{Zn}, \mathrm{Fe}, \mathrm{Mn}$, and Co (Feigl et al., 2013). Elevated Cu-mediated reduction in $\mathrm{Zn}$ in rapeseed has also been reported (Ivanova et al., 2010). In Suaeda fruticosa, $\mathrm{Cu}^{2+}$ increased $\mathrm{K}^{+}$contents in the shoots; however, $\mathrm{Cu}^{2+}$ showed no effect on the level of $\mathrm{Mg}^{2+}$ and $\mathrm{Na}^{+}$in the shoots (Bankaji et al., 2015). In a recent study on $\mathrm{Cu}$-exposed oat cultivars (Avena sativa L. cv. Fronteira and cv. Perona), Marastoni et al. (2019a) reported a higher accumulation of $\mathrm{Cu}$ in the apoplasm which was argued to strongly reduce the available binding sites, leading eventually to a competitive absorption with $\mathrm{Ca}, \mathrm{Mn}$, and $\mathrm{Zn}$.

\section{NO as a Major Plant Signaling Molecule}

As a key signaling component, $\mathrm{NO}$ is involved in various physiological and metabolic processes in plants including their adaptation to various stresses (Asgher et al., 2017; Fancy et al., 2017; Santisree et al., 2019). In plants, NO is synthesized both by enzymatic and non-enzymatic systems (Arasimowicz and Floryszak-Wieczorek, 2007; Hasanuzzaman et al., 2018) (Figure 1). Contingent to its concentration and the site of production NO shows both positive and negative effects. Further NO was seen to affect major metabolic pathways in plants, particularly of nutrient assimilation. Our recent research on NO suggests that salt stress effects on the photosynthetic performance are mitigated effectively when NO was applied along with the split application of both $\mathrm{N}$ and $\mathrm{S}$, and the photosynthetic activity was stimulated through increased $\mathrm{N}$ and $\mathrm{S}$ assimilation and antioxidant system conferring tolerance against salt stress (Jahan et al., 2020). Similarly. NO was also shown to reverse glucosemediated photosynthetic inhibition in T. aestivum L. under salt stress (Sehar et al., 2019). We have also shown that NO can improve S-assimilation and GSH production under $\mathrm{Cd}$ stress and prevent inhibitory photosynthesis in mustard (Fatma et al., 2016a,b; Per et al., 2017b). Usually, NO transmits its bioactivity by targeting proteins during post-translational modifications via cysteine $S$-nitrosylation that leads to the formation of $S$ nitrosothiols (SNOs). The reaction of NO with ROS such as superoxide anions also leads to the protein tyrosine nitration and yields nitrite (ONOO-). In fact, SNOs are the key signaling molecules largely involved in response to several stresses in plant biology (Begara-Morales et al., 2019). Generated as a result of the reaction of NO with reduced GSH, S-nitrosoglutathione (GSNO) is the most important among SNOs. This metabolite is considered as a major reservoir of NO. As a NO-reservoir, GSNO can be transported to other cells/tissues which confer NO as a long distance mobile signaling molecule. GSNO can also be converted into oxidized glutathione (GSSG) and $\mathrm{NH}_{3}$ by GSNO reductase (GSNOR) (Fancy et al., 2017; Begara-Morales et al., 2018). In addition, a direct donation of the NO group of GSNO to other cellular thiols may occur via $S$-transnitrosylation reactions (Corpas et al., 2013). NO-dependent modifications in plant lipids such as nitro-fatty acids $\left(\mathrm{NO}_{2}-\mathrm{FA}\right)$ have shown the importance of NO in cell signaling processes (Sánchez-Calvo et al., 2013; Fazzari et al., 2014). $\mathrm{NO}_{2}$-FA such as linolenic acid has been reported to alleviate various abiotic stresses (Mata-Pérez et al., 2016). A NO-mediated pathway is also involved in the activation of mitogen-activated protein kinase (MAPK) signaling events (Pagnussat et al., 2004) and in the promotion of MPK6-mediated caspase-3-like activation (Ye et al., 2013).

\section{NO IN PLANT GROWTH AND DEVELOPMENT}

NO plays a vital role in regulating several processes related to plant growth and development, and qualifies the definition of plant growth regulators (Beligni and Lamattina, 2001; Xiong et al., 2009; Takahashi and Morikawa, 2014). The role of NO has been elucidated in growth and development of plants such 


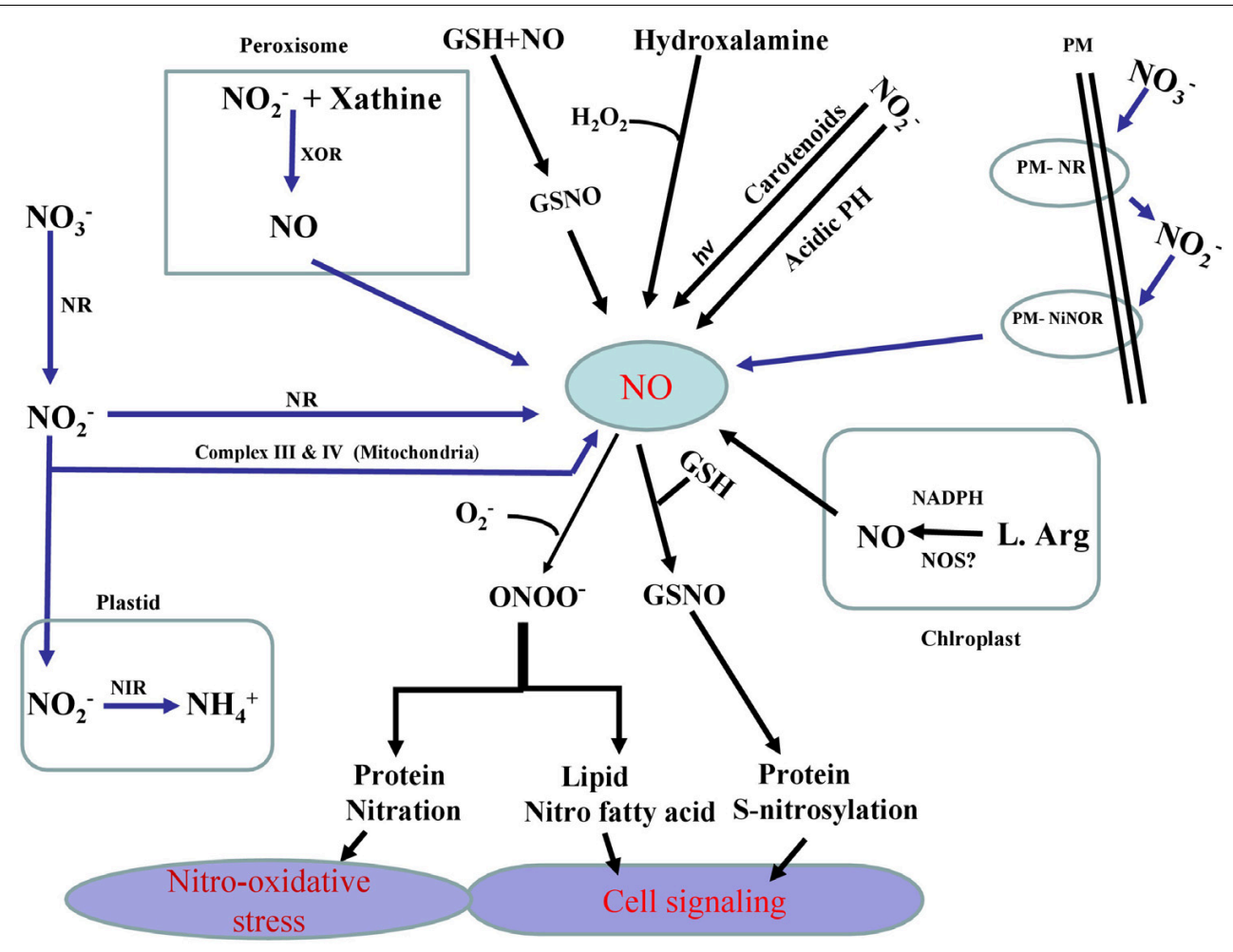

FIGURE 1 | Schematic representation of the pathways (enzymatic and non-enzymatic) and their major components involved in the generation of nitric oxide (NO) in plants. Enzymatic production of NO depends on NADPH dependent oxidation of L-Arg via NO synthase (NOS)-like activity and also nitrate reductase (NR) which converts nitrate $\left(\mathrm{NO}_{3}{ }^{-}\right)$to nitrite $\left(\mathrm{NO}_{2}{ }^{-}\right)$and later $\left(\mathrm{NO}_{2}{ }^{-}\right)$reduction into $\mathrm{NO}$ via NR itself or via electron transport chain in mitochondria. Specific plasma membrane-bound nitrate and nitrite: nitric oxide reductase (PM-NR/Ni:NOR) activity utilizes $\mathrm{NO}_{2}{ }^{-}$as a substrate to generate NO. Another possible route for NO formation is carried out by xanthine oxidoreductase (XOR). Non-enzymatic sources also result in the reduction of (nitrogen dioxide) $\mathrm{NO}_{2}$ to $\mathrm{NO}_{\text {by }}$ carotenoids. In non-enzymatic pathway of $\mathrm{NO}$ generation that operates under sufficiently acidic medium and $\mathrm{NO}_{2}^{-}$gives rise $\mathrm{NO}$ and $\mathrm{O}_{2}$. $\mathrm{NO}$ generated in various pathways reacts with reduced GSH to produce S-nitrosoglutathione (GSNO), a donor and major reservoir of NO. It is also clear that NO directly modifies target proteins through reacting with reactive oxygen species (ROS) including superoxide, to generate peroxynitrite (ONOO-) which in turn causes nitrosative stress via protein tyrosine nitration. On the other, NO can also directly control cellular thiols via S-transnitrosylation reaction.

as seed germination, senescence, root growth, leaf expansion, photo-morphogenesis, floral regulation, photosynthesis, root organogenesis, hypocotyl growth, and pathogen defense (Asgher et al., 2017; Corpas and Palma, 2018; Santisree et al., 2019), stomatal closure and the cytokinin signaling pathway (Tun et al., 2001; Desikan et al., 2004; Shi et al., 2015). Contingent to its concentration and the site of formation NO induces both positive and negative effects on plant metabolic processes. At lower concentrations, NO exhibited important positive effects in plants where it modulated germination, leaf expansion, and detoxification. On the other, several negative effects such as inhibition of photosynthesis, nitrosative stress, chlorophyll degradation were also noticed at much higher concentrations of NO (Zottini et al., 2002; Antoniou et al., 2013). In wheat seedlings, the rate of leaf expansion increased at lower concentrations of NO; however, no beneficial effect was observed at its higher concentrations (Tian and Lei, 2006). In maize, low concentration of NO promoted root growth, and its higher concentration inhibited the root growth (Lombardo et al., 2006). In a similar work, low concentration of NO $(100 \mu \mathrm{M})$ stimulated growth of Medicago truncatula; whereas, a decreased growth was observed with higher concentration of NO (2.5 mM) (Filippou et al., 2013). The authors showed that $2.5 \mathrm{mM}$-mediated declines in photosynthetic rate, stomatal response, intracellular proline and putrescine accumulation and decreased $M$. truncatula growth (Filippou et al., 2013). Different dose of NO donors can differentially induce the elongation of root tips. To this end, an inhibited growth of hypocotyls in Arabidopsis, lettuce, and potato was observed with the treatment of $0.1 \mathrm{mM}$ sodium nitroprusside (SNP), a NO-donor (Beligni and Lamattina, 2000). SNP was also reported to induce root development in Zea mays (Gouvea et al., 1997; Corpas and Barroso, 2015a). However, methylene blue, a NO-scavenger was reported to exhibit positive effects on the root development (Gouvea et al., 1997). Compared to $\mathrm{GA}_{3}$, NO was reported to exhibit its significant role in breaking the dormancy of lettuce seeds (Beligni and Lamattina, 2000). NO can also control growth and re-orientation of pollen tubes (Prado et al., 2004), induce the lateral roots mediated by the plant growth- promoting Rhizobacterium azospirillum (Creus et al., 2005).

The role of NO in photosynthesis has rarely been investigated. However the NO-mediated moderate improvement in photosynthetic performance of Solanum melongena seedlings 
was argued as a result of excessive quenching energy and an increase in quantum yield of PSII (Wu et al., 2013). NO with sulfur improved antioxidant defense system modulating stomatal behavior and sulfur assimilation in Brassica juncea (Fatma et al., 2016a). In cucumber seedlings, exogenous NO showed increased chlorophyll content, improved photosynthetic rate, transpiration rate and stomatal conductance (Fan et al., 2007). However, in Phaseolus aureus, NO reduced the activity of ribulose-1, 5-bisphosphate carboxylase/oxygenase (Rubisco) and increased the content of PSII oxygen-evolving complex (Lum et al., 2005). In Kalanchoe pinnata, NO inhibited Rubisco activity by $S$-nitrosylation in a dose-dependent manner and also slowed down photosynthetic rate (Abat et al., 2008). In Phaseolus vulgaris guard cells, NO showed decreased activity of the $\mathrm{H}^{+}$-ATPase (Ördög et al., 2013). At cellular level, NO breaks the chain reactions of oxidation and limits oxidative damage (Bakakina et al., 2014). NO can also prevent the generation of toxic hydroxyl radicals by binding with the superoxide radicals produced in the chloroplast and mitochondria during the process of electron transport chain (Arora et al., 2016). Due to its signaling nature $\mathrm{NO}$ was reported to upregulate the expression of certain genes to counteract oxidative damage (Jiao et al., 2016). NO also triggers the upregulation of genes such as that of chalcone synthase (CHS), glutathione-S-transferase (GST), alternative oxidase (AOX1a) and glutathione peroxidase (GPX) (Murgia et al., 2004). It has also been reported to deter gene expression of thylakoid ascorbate peroxidase (tAPX) controlling oxidative position of plant cell (Murgia et al., 2004).

\section{NO-MEDIATED COPPER-TOLERANCE IN PLANTS}

Role of NO in minimization of heavy metal stress in plants has been extensively studied (Laspina et al., 2005; Arasimowicz and Floryszak-Wieczorek, 2007; Xiong et al., 2009; Jhanji et al., 2012; Leterrier et al., 2012; Chmielowska-Bąk et al., 2014; Per et al., 2017b; Rizwan et al., 2018; Ahmad et al., 2018; Li et al., 2018) (Table 2). However, mechanisms underlying NOmediated control of plant responses to elevated $\mathrm{Cu}$-impacts are still elusive. There are two possible strategies that NO might use to mitigate heavy metal stress in plants. As the first approach, elevated $\mathrm{Cu}$-exposed plants tend to upregulate their antioxidant enzymes activity or express genes involved in defense mechanism (Rizwan et al., 2018). Secondly, NO maintains the equilibrium of cellular free metal concentration either by excluding heavy metals through roots or by keeping a check on their cellular accumulation to a toxic level $(\mathrm{Oz}$ et al., 2015). The action mechanisms potentially involved in NOmediated plant $\mathrm{Cu}$-tolerance have been illustrated in Figure 2. The outcomes of the studies analyzing the role of NO-application in $\mathrm{Cu}$-stressed plants revealed that $\mathrm{NO}$ reduces $\mathrm{Cu}$-induced oxidative stress by increasing the activities of antioxidant enzymes; maintaining cellular redox homeostasis by elimination of ROS, and thereby promoting normal metabolic function (Cui et al., 2009; Zhang et al., 2009). The supply of sodium nitroprusside (SNP), a NO-donor to $\mathrm{Cu}$-exposed Panax ginseng

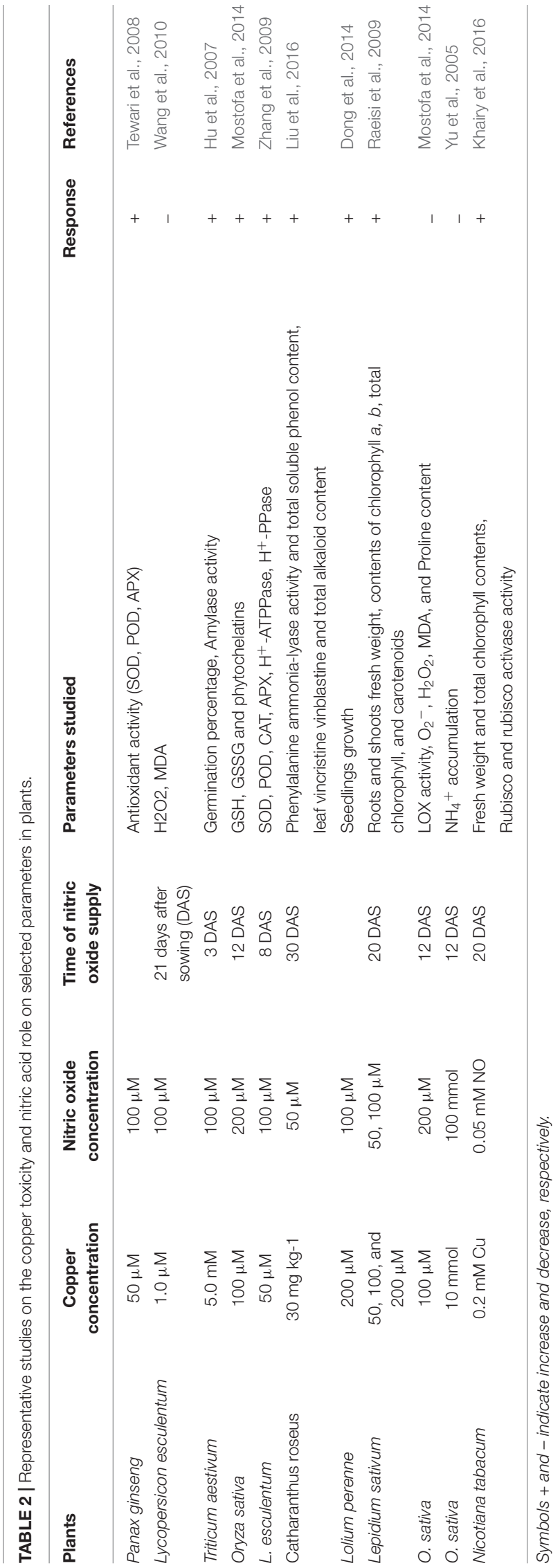




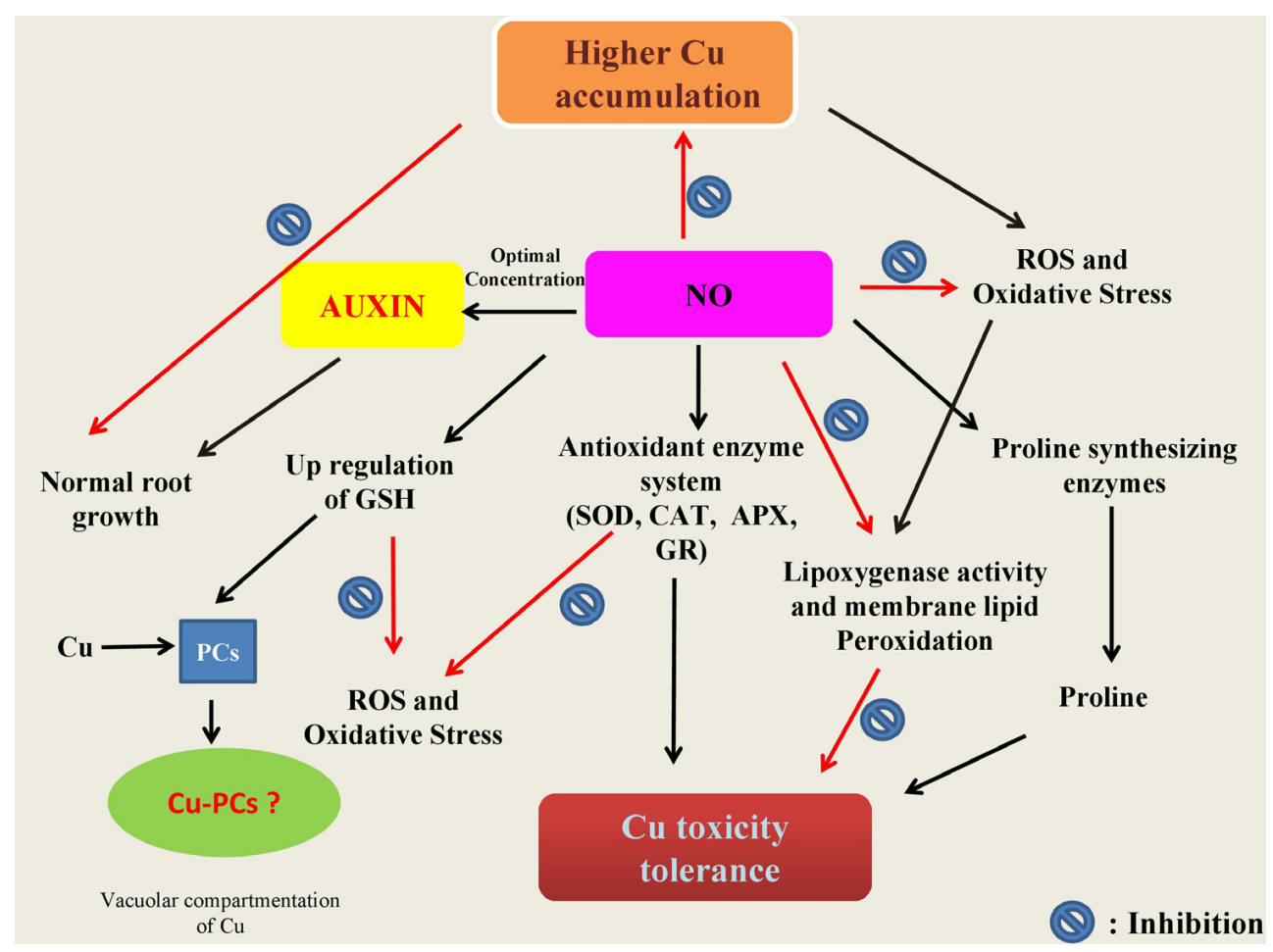

FIGURE 2 | Schematic representation of the potential mechanisms underlying protective roles of nitric oxide (NO) in plants. In summary: (a) NO is involved in cellular homeostasis under Cu stress by inducing/modulating enzymes (CAT, catalase; APX, ascorbate peroxidase; GR, glutathione reductase) and non-enzyme including reduced glutathione (GSH) directly and/or indirectly involved the scavenging of reactive oxygen species (ROS); (b) NO can also be involved in the stimulation of the key enzymes of proline synthesis and thereby in modulation of the cellular proline and also in inhibition of lipoxygenase activity which in turn leads to membrane lipid peroxidation; and (c) once in cell, $\mathrm{Cu}$ ions make complex with phytochelatins (PCS) known to be induced by low molecular weight peptides (such as GSH) in the cytosol. The Cu-PC complexes are high molecular weight and are subsequently transported to the vacuole and thereby protect ill consequences of elevated Cu ions.

modulated the activity of $\mathrm{H}_{2} \mathrm{O}_{2}$-metabolizing enzymes including catalase (CAT), peroxidase, and ascorbate peroxidase (APX), and thereby increased the detoxification of $\mathrm{H}_{2} \mathrm{O}_{2}$ in roots (Tewari et al., 2008). Pre-treatment of Triticum aestivum with $\mathrm{NO}$ was reported to reverse the inhibitory effect of $\mathrm{Cu}$ stress by increasing the activity of superoxide dismutase (SOD) and CAT, and reducing the lipoxygenase activity and membrane lipid peroxidation ( $\mathrm{Hu}$ et al., 2007). Besides inducing antioxidant system, supplied $\mathrm{NO}$ was also reported to promote the activity of $\mathrm{H}^{+}$-ATPase and $\mathrm{H}^{+}$-PPase in the plasma membrane or tonoplast which might play important role in tolerance to $\mathrm{Cu}$ stress by maintaining cytoplasmic pH (Cui et al., 2009; Zhang et al., 2009). The supplied NO-mediated escalation in the level of GSH has also been reported (Zhang et al., 2019). GSH has central role in plants in maintaining cellular redox potential (Anjum et al., 2014; Ahmad et al., 2020). Recently, Mostofa et al. (2014) reported alleviation of $\mathrm{Cu}$ induced toxicity in Oryza sativa seedlings mainly as a result of interaction between $\mathrm{NO}$ and GSH. The authors revealed that the supply of SNP $(200 \mu \mathrm{M})$ alone or in combination with GSH $(200 \mu \mathrm{M})$ minimized $\mathrm{Cu}$-impacts by reducing $\mathrm{Cu}$ uptake and eased the $\mathrm{Cu}$-induced oxidative damage by amending GSH production. Not only GSH content was increased but also increased the content of ascorbate (AsA), and the ratios of GSH/GSSG and AsA/DHA, which in turn strengthened antioxidant defense system improved $\mathrm{Cu}$-tolerance. Moreover the contribution of different metal-chelating ligands, such as metallothioneins (MTs) and phytochelatins (PCs) are crucial players and plays pivotal role in conferring resistance to heavy metal tolerance in plants dealing with high concentrations of various metal inclusion (Cobbett and Goldsbrough, 2002; Anjum et al., 2015a; Chaudhary et al., 2018). Exogenous $\mathrm{NO}$ can also regulate the oxidation-reduction status of GSHGSSG, control the GSH-PC metabolism, and also promote the vascular compartmentalization of excessive $\mathrm{Cu}$ in Lemna esculentum (Wang et al., 2018). In addition, MTs-responsive genes were induced by NO in Solanum lycopersicum and this NO-induced expression of MTs-related genes were reversed by NO scavenger [2-(4-carboxyphenyl)-4,4,5,5-tetramethylimidazoline-1-oxyl-3-oxide potassium salt (cPTIO)], NOS inhibitor [Nnitro-l-arginine methyl ester (L-NAME)] and NR inhibitor (tungstate), which confirmed the involvement of MTs in NOmediated tolerance to Cu toxicity (Wang et al., 2010).

Proline, a multifunctional amino acid have diverse roles in response to stress conditions, such as in stabilization of proteins, subcellular structures and membranes and protecting cellular functions by scavenging ROS potentiate plant to survive under stress (Anjum et al., 2014; Kaur and Asthir, 2015; 
Per et al., 2017b). The Cu-exposure accrued accumulation of proline has been found as a common response reported in several plant species (Zhang et al., 2008; Fidalgo et al., 2013; Mostofa et al., 2014). Cu-exposure caused increase in the endogenous NO production was found to modulate the cellular proline through stimulating the activity of the key proline-synthesizing enzymes such as pyrroline-5-carboxylate synthetase (Zhang et al., 2008). However, the correlation between $\mathrm{NO}$ content and $\mathrm{Cu}-$ induced proline accumulation in plants is not always apparent. For example proline content increased upon $\mathrm{Cu}$-exposure but failed upon application of NO (Mostofa et al., 2014). Therefore, it indicates that the regulation of antioxidant system by NO is also dependent on the exposure conditions and the model plant. Photosynthetic functions are typically affected either directly or indirectly by elevated levels of $\mathrm{Cu}$. In $\mathrm{Cu}$-exposed grown Chlorella, NO application takes down the inhibition levels of $\mathrm{O}_{2}$ fixation, $\mathrm{O}_{2}$ evolution, and maximum quantum yield of PS II and also ominously diminished the oxidative burst (Kumar Singh et al., 2004). In another study, addition of 50, 100, $200 \mu \mathrm{M}$ SNP protected Lolium perenne against $\mathrm{Cu}$-toxicity as a result of increased chlorophyll content and photosynthesis, induced antioxidant enzyme activities, reduced $\mathrm{Cu}$-induced oxidative damages, maintained intracellular ion equilibrium, and limited $\mathrm{Cu}$ translocation from roots to shoots (Dong et al., 2014). NO was found to scavenge $\mathrm{ROS}$ and control $\mathrm{NH}_{4}{ }^{+}$ accumulation in $\mathrm{Cu}$-exposed $\mathrm{O}$. sativa leaves ( $\mathrm{Yu}$ et al., 2005). In $\mathrm{Cu}(50 \mu \mathrm{M})$-exposed Arabidopsis seedlings, NO escalated the $\mathrm{Cu}$ induced cotyledon expansion but alleviated cotyledon elongation processes (Petó et al., 2011).

In naked barley (without hull), $\mathrm{Cu}$-tolerance involved nitrate reductase-mediated NO-production (Hu et al., 2015). Further NO-mediated strengthening of antioxidant defense system and the control of oxidative stress and cell death was also shown (Hu, 2016). In Catharanthus roseus, SNP ameliorated Cu-toxicity by decreasing the ROS-burst, promoting the contents of amino acids and the total phenolic in the roots, regulating mineral absorption and re-establishing ATPase activities (Liu et al., 2016). Yuan et al. (2013) have reported that the Cu stress in Arabidopsis affects root elongation by redistributing PIN1-mediated auxin (AUX). These witnessed phenotypic changes in $\mathrm{Cu}$-effected roots are possibly due to AUX action, because in roots, the pattern of AUX distribution is vital for healthy root development. In addition to this Fernández-Marcos et al. (2011) showed that mutant cue1/noxl changes NO levels, and high level of NO hampered the length of root apical meristem in Arabidopsis, and reduced transport of AUX and its response by altering the

\section{REFERENCES}

Abat, J. K., Mattoo, A. K., and Deswal, R. (2008). S-nitrosylated proteins of a medicinal CAM plant Kalanchoe pinnata-ribulose-1, 5-bisphosphate carboxylase/oxygenase activity targeted for inhibition. FEBS J. 275, 2862-2872. doi: 10.1111/j.1742-4658.2008.06425.x

Abdel-Ghany, S. E., and Pilon, M. (2008). MicroRNA-mediated systemic downregulation of copper protein expression in response to low copper availability in Arabidopsis. J. Biol. Chem. 283, 15932-15945. doi: 10.1074/jbc.M801406200
PIN1 levels. Therefore, the supply of optimal level of NO might be a responsible for maintaining the AUX concentration and its distribution when plants countered the heavy metal stress (Figure 2). In Arabidopsis, prolonged exposure of $\mathrm{Cu}$ impacted $\mathrm{NO}$ and AUX metabolism, and it was revealed that NO could improve $\mathrm{Cu}$-induced inhibition of both root and stem growth by attenuating PIN1 induced AUX transport (Kolbert et al., 2012). In another report, Kolbert et al. (2015) established the relationship of the low $\mathrm{Cu}$-sensitivity of nia1nia2noa1-2 mutant with the availability therein of low NO level and suggested that the contribution of the NR and NO associated 1-dependent pathways to NO synthesis. Thus, the above results pointed out that $\mathrm{NO}$ plays a vital role in response to $\mathrm{Cu}$ stress. However, there is still limitations in understanding the exact mechanism of NO action under $\mathrm{Cu}$ stress, and there is an utmost need to further investigate focusing more into molecular insights of $\mathrm{NO}$ action under Cu stress.

\section{CONCLUSION AND PROSPECTS}

This review appraised the literature available on $\mathrm{Cu}$-induced toxicity and its NO-mediated amelioration and underlying mechanisms in plants. It is clear that NO is a diffusible gaseous molecule and plays a key role in performing a number of biological functions in plants. NO acts as a signaling molecule in inducing the antioxidant system during oxidative stress. There is a remarkable progress in our understanding on the biological role of $\mathrm{NO}$ in plants particularly in case of salt stress. However, least information is available on the response of $\mathrm{NO}$ on $\mathrm{Cu}$ stress. Insights are required into the signaling pathways and the direct targets of NO particularly in Cu-exposed plants. Examination of the $\mathrm{Cu}$-induced modulation of the NO biosynthetic pathways and its involvement in the physiological roles of NO in plants would be imperative in this regard. Some of the biosynthetic pathways of NO in plants are well known but how these pathways are interconnected and what is the mode of action in each tissue and organ are required to be elucidated.

\section{AUTHOR CONTRIBUTIONS}

AM and NK conceived the idea. BR, ZS, and AM prepared the first draft. NA, AM, and NK corrected and improved the manuscript. All authors approved the final version for its publication.

Adrees, M., Ali, S., Rizwan, M., Ibrahim, M., Abbas, F., Farid, M., et al. (2015). The effect of excess copper on growth and physiology of important food crops: a review. Environ. Sci. Pollut. Res. 22, 8148-8162. doi: 10.1007/s11356-015-44965

Aguirre, G., and Pilon, M. (2016). Copper delivery to chloroplast proteins and its regulation. Front. Plant Sci. 6:1250. doi: 10.3389/fpls.2015.01250

Ahmad, M., Anjum, N. A., Asif, A., and Ahmad, A. (2020). Real-time monitoring of glutathione in living cells using genetically encoded FRET-based ratiometric nanosensor. Sci. Rep. 10:992. doi: 10.1038/s41598-020-57654-y 
Ahmad, P., Ahanger, M. A., Alyemeni, M. N., Wijaya, L., and Alam, P. (2018). Exogenous application of nitric oxide modulates osmolyte metabolism, antioxidants, enzymes of ascorbate-glutathione cycle and promotes growth under cadmium stress in tomato. Protoplasma 255, 79-93. doi: 10.1007/s00709017-1132-x

Ali, N. A., Bernal, M. P., and Ater, M. (2002). Tolerance and bioaccumulation of copper in Phragmites australis and Zea mays. Plant Soil 239, 103-111. doi: 10.1023/A:1014995321560

Ali, S., Rizwan, M., Ullah, N., Bharwana, S. A., Waseem, M., Farooq, M. A., et al. (2016). Physiological and biochemical mechanisms of silicon-induced copper stress tolerance in cotton (Gossypium hirsutum L.). Acta Physiol. Plant. 38:262. doi: 10.1007/s11738-016-2279-3

Ambrosini, V. G., Rosa, D. J., de Melo, G. W., Zalamena, J., Cella, C., Simão, D. G., et al. (2018). High copper content in vineyard soils promotes modifications in photosynthetic parameters and morphological changes in the root system of 'Red Niagara'plantlets. Plant Physiol. Biochem. 128, 89-98. doi: 10.1016/j. plaphy.2018.05.011

Andrés-Bordería, A., Andrés, F., Garcia-Molina, A., Perea-García, A., Domingo, C., Puig, S., et al. (2017). Copper and ectopic expression of the Arabidopsis transport protein COPT1 alter iron homeostasis in rice (Oryza sativa L.). Plant Mol. Biol. 95, 17-32. doi: 10.1007/s11103-017-0622-8

Andrés-Colás, N., Carrió-Seguí, A., Abdel-Ghany, S. E., Pilon, M., and Peñarrubia, L. (2018). Expression of the intracellular COPT3-mediated $\mathrm{Cu}$ transport is temporally regulated by the TCP16 transcription factor. Front. Plant Sci. 9:910. doi: $10.3389 /$ fpls.2018.00910

Anjum, N. A., Aref, I. M., Duarte, A. C., Pereira, E., Ahmad, I., and Iqbal, M. (2014). Glutathione and proline can coordinately make plants withstand the joint attack of metal(loid) and salinity stresses. Front. Plant Sci. 5:662. doi: $10.3389 /$ fpls.2014.00662

Anjum, N. A., Hasanuzzaman, M., Hossain, M. A., Thangavel, P., Roychoudhury, A., Gill, S. S., et al. (2015a). Jacks of metal/metalloid chelation trade in plants an overview. Front. Plant Sci. 6:192. doi: 10.3389/fpls.2015.00192

Anjum, N. A., Singh, H. P., Khan, M. I. R., Masood, A., Per, T. S., Negi, A., et al. (2015b). Too much is bad-an appraisal of phytotoxicity of elevated plantbeneficial heavy metal ions. Environ. Sci. Pollut. Res. 22, 3361-3382. doi: 10. 1007/s11356-014-3849-9

Antoniou, C., Filippou, P., Mylona, P., Fasoula, D., Ioannides, I., Polidoros, A., et al. (2013). Developmental stage-and concentration-specific sodium nitroprusside application results in nitrate reductase regulation and the modification of nitrate metabolism in leaves of Medicago truncatula plants. Plant Signal. Behav. 8:e25479. doi: 10.4161/psb.25479

Arasimowicz, M., and Floryszak-Wieczorek, J. (2007). Nitric oxide as a bioactive signalling molecule in plant stress responses. Plant Sci. 172, 876-887. doi: 10. 1016/j.plantsci.2007.02.005

Arora, D., Jain, P., Singh, N., Kaur, H., and Bhatla, S. C. (2016). Mechanisms of nitric oxide crosstalk with reactive oxygen species scavenging enzymes during abiotic stress tolerance in plants. Free Radic. Res. 50, 291-303. doi: 10.3109/ 10715762.2015.1118473

Asgher, M., Khan, M. I. R., Anjum, N. A., Verma, S., Vyas, D., Per, T. S., et al. (2018a). Ethylene and polyamines in counteracting heavy metal phytotoxicity: a crosstalk perspective. J. Plant Growth Regul. 37, 1050-1065. doi: 10.1007/ s00344-018-9823-x

Asgher, M., Per, T. S., Masood, A., Fatma, M., Freschi, L., Corpas, F. J., et al. (2017). Nitric oxide signaling and its crosstalk with other plant growth regulators in plant responses to abiotic stress. Environ. Sci. Pollut. Res. 24, 2273-2285. doi: 10.1007/s11356-016-7947-8

Asgher, M., Per, T. S., Verma, S., Pandith, S. A., Masood, A., and Khan, N. A. (2018b). Ethylene supplementation increases PSII efficiency and alleviates chromium-inhibited photosynthesis through increased nitrogen and sulfur assimilation in mustard. J. Plant Growth Regul. 37, 1300-1317. doi: 10.1007/ s00344-018-9858-Z

Astier, J., Gross, I., and Durner, J. (2017). Nitric oxide production in plants: an update. J. Exp. Bot. 69, 3401-3411. doi: 10.1093/jxb/erx420

Azeez, M., Adesanwo, O., and Adepetu, J. (2015). Effect of Copper (Cu) application on soil available nutrients and uptake. Afr. J. Agric. Res. 10, 359-364. doi: 10.5897/AJAR2014.9010

Bakakina, Y., Kolesneva, E., Dubovskaya, L., and Volotovski, I. (2014). "Cytoprotective role of nitric oxide under oxidative stress," in Nitric Oxide in
Plants: Metabolism and Role in Stress Physiology, eds M. N. Khan, M. Mobin, F. Mohammad, and F. J. Corpas (Cham: Springer), 199-210. doi: 10.1007/978-3319-06710-0_12

Baker, D. E., and Senef, J. P. (1995). “Copper," in Heavy Metals in Soils, ed. B. J. Alloway (London: Blackie Academic and Professional), 179-205.

Bankaji, I., Caçador, I., and Sleimi, N. (2015). Physiological and biochemical responses of Suaeda fruticosa to cadmium and copper stresses: growth, nutrient uptake, antioxidant enzymes, phytochelatin, and glutathione levels. Environ. Sci. Pollut. Res. 22, 13058-13069. doi: 10.1007/s11356-015-4414-x

Barbosa, R. H., Tabaldi, L. A., Miyazaki, F. R., Pilecco, M., Kassab, S. O., and Bigaton, D. (2013). Foliar copper uptake by maize plants: effects on growth and yield. Ciênc. Rural 43, 1561-1568. doi: 10.1590/S0103-84782013000900005

Begara-Morales, J. C., Chaki, M., Valderrama, R., Mata-Pérez, C., Padilla, M. N., and Barroso, J. B. (2019). The function of S-nitrosothiols during abiotic stress in plants. J. Exp. Bot. 70, 4429-4439. doi: 10.1093/jxb/erz197

Begara-Morales, J. C., Chaki, M., Valderrama, R., Sánchez-Calvo, B., Mata-Pérez, C., Padilla, M. N., et al. (2018). Nitric oxide buffering and conditional nitric oxide release in stress response. J. Exp. Bot. 69, 3425-3438. doi: 10.1093/jxb/ ery072

Beligni, M., and Lamattina, L. (2001). Nitric oxide in plants: the history is just beginning. Plant Cell Environ. 24, 267-278. doi: 10.1046/j.1365-3040.2001. 00672.x

Beligni, M. V., and Lamattina, L. (2000). Nitric oxide stimulates seed germination and de-etiolation, and inhibits hypocotyl elongation, three light-inducible responses in plants. Planta 210, 215-221. doi: 10.1007/PL00008128

Bernal, M., Casero, D., Singh, V., Wilson, G. T., Grande, A., Yang, H., et al. (2012). Transcriptome sequencing identifies SPL7-regulated copper acquisition genes FRO4/FRO5 and the copper dependence of iron homeostasis in Arabidopsis. Plant Cell 24, 738-761. doi: 10.1105/tpc.111.090431

Bouazizi, H., Jouili, H., Geitmann, A., and El Ferjani, E. (2010). Copper toxicity in expanding leaves of Phaseolus vulgaris L.: antioxidant enzyme response and nutrient element uptake. Ecotoxicol. Environ. Saf. 73, 1304-1308. doi: 10.1016/ j.ecoenv.2010.05.014

Bowler, C., Van Camp, W., Van Montagu, M., Inzé, D., and Asada, K. (1994). Superoxide dismutase in plants. Crit. Rev. Plant. Sci. 13, 199-218. doi: 10.1080/ 07352689409701914

Brunetto, G., Bastos de Melo, G. W., Terzano, R., Del Buono, D., Astolfi, S., Tomasi, N., et al. (2016). Copper accumulation in vineyard soils: rhizosphere processes and agronomic practices to limit its toxicity. Chemosphere 162, 293-307. doi: 10.1016/j.chemosphere.2016.07.104

Casareno, R. L. B., Waggoner, D., and Gitlin, J. D. (1998). The copper chaperone CCS directly interacts with copper/zinc superoxide dismutase. J. Biol. Chem. 273, 23625-23628. doi: 10.1074/jbc.273.37.23625

Chatterjee, J., and Chatterjee, C. (2000). Phytotoxicity of cobalt, chromium and copper in cauliflower. Environ. Pollut. 109, 69-74. doi: 10.1016/S0269-7491(99) 00238-9

Chaudhary, K., Agarwal, S., and Khan, S. (2018). "Role of phytochelatins (PCs), metallothioneins (MTs), and heavy metal ATPase (HMA) genes in heavy metal tolerance," in Mycoremediation and Environmental Sustainability, ed. R. Prasad (Cham: Springer), 39-60. doi: 10.1007/978-3-319-77386-5_2

Chen, J., Shafi, M., Li, S., Wang, Y., Wu, J., Ye, Z., et al. (2015). Copper induced oxidative stresses, antioxidant responses and phytoremediation potential of Moso bamboo (Phyllostachys pubescens). Sci. Rep. 5:13554. doi: 10.1038/ srep 13554

Chmielowska-Bąk, J., Gzyl, J., Ruciñska-Sobkowiak, R., Arasimowicz-Jelonek, M., and Deckert, J. (2014). The new insights into cadmium sensing. Front. Plant Sci. 5:245. doi: 10.3389/fpls.2014.00245

Chu, C. C., Lee, W. C., Guo, W. Y., Pan, S. M., Chen, L. J., Li, H. M., et al. (2005). A copper chaperone for superoxide dismutase that confers three types of copper/zinc superoxide dismutase activity in Arabidopsis. Plant Physiol. 139, 425-436. doi: 10.1104/pp.105.065284

Ciscato, M., Valcke, R., Van Loven, K., Clijsters, H., and NavariIzzo, F. (1997). Effects of in vivo copper treatment on the photosynthetic apparatus of two Triticum durum cultivars with different stress sensitivity. Physiol. Plant. 100, 901-908. doi: 10.1111/j.1399-3054.1997.tb00016.x

Cobbett, C., and Goldsbrough, P. (2002). Phytochelatins and metallothioneins: roles in heavy metal detoxification and homeostasis. Annu. Rev. Plant Biol. 53, 159-182. doi: 10.1146/annurev.arplant.53.100301.135154 
Cohu, C. M., and Pilon, M. (2010). “Cell biology of copper,' in Cell Biology of Metals and Nutrients, eds R. Hell, and R.-R. Mendel (Berlin: Springer), 55-74. doi: 10.1007/978-3-642-10613-2_3

Cona, A., Rea, G., Angelini, R., Federico, R., and Tavladoraki, P. (2006). Functions of amine oxidases in plant development and defence. Trends Plant Sci. 11, 80-88. doi: 10.1016/j.tplants.2005.12.009

Constabel, C. P., and Barbehenn, R. (2008). "Defensive roles of polyphenol oxidase in plants," in Induced Plant Resistance to Herbivory, ed. A. Schaller (Berlin: Springer), 253-270. doi: 10.1007/978-1-4020-8182-8_12

Corpas, F., and Palma, J. (2018). Assessing nitric oxide (NO) in higher plants: an outline. Nitrogen 1, 12-20. doi: 10.3390/nitrogen1010003

Corpas, F. J., Alché, J. D. D., and Barroso, J. B. (2013). Current overview of S-nitrosoglutathione (GSNO) in higher plants. Front. Plant Sci. 4:126. doi: 10.3389/fpls.2013.00126

Corpas, F. J., and Barroso, J. B. (2015a). Functions of nitric oxide (NO) in roots during development and under adverse stress conditions. Plants 4, 240-252. doi: 10.3390/plants4020240

Corpas, F. J., and Barroso, J. B. (2015b). Nitric oxide from a "green" perspective. Nitric Oxide 45, 15-19. doi: 10.1016/j.niox.2015.01.007

Creus, C. M., Graziano, M., Casanovas, E. M., Pereyra, M. A., Simontacchi, M., Puntarulo, S., et al. (2005). Nitric oxide is involved in the Azospirillum brasilense-induced lateral root formation in tomato. Planta 221, 297-303. doi: 10.1007/s00425-005-1523-7

Cui, X., Zhang, Y., Chen, X., Jin, H., and Wu, X. (2009). "Effects of exogenous nitric oxide protects tomato plants under copper stress," in Proceedings of the 2009 3rd International Conference on Bioinformatics and Biomedical Engineering, (Beijing: IEEE), 1-7. doi: 10.1109/ICBBE.2009.5162740

de Freitas, T. A., França, M. G. C., De Almeida, A.-A. F., De Oliveira, S. J. R., De Jesus, R. M., Souza, V. L., et al. (2015). Morphology, ultrastructure and mineral uptake is affected by copper toxicity in young plants of Inga subnuda subs. luschnathiana (Benth.) TD Penn. Environ. Sci. Pollut. Res. Int. 22, 15479-15494. doi: $10.1007 /$ s11356-015-4610-8

de Rienzo, F., Gabdoulline, R., Menziani, M. C., and Wade, R. (2000). Blue copper proteins: a comparative analysis of their molecular interaction properties. Protein Sci. 9, 1439-1454. doi: 10.1110/ps.9.8.1439

Desikan, R., Cheung, M. K., Bright, J., Henson, D., Hancock, J. T., and Neill, S. J. (2004). ABA, hydrogen peroxide and nitric oxide signalling in stomatal guard cells. J. Exp. Bot. 55, 205-212. doi: 10.1093/jxb/erh033

Domingos, P., Prado, A. M., Wong, A., Gehring, C., and Feijo, J. A. (2015). Nitric oxide: a multitasked signaling gas in plants. Mol. Plant 8, 506-520. doi: 10.1016/j.molp.2014.12.010

Dong, Y., Xu, L., Wang, Q., Fan, Z., Kong, J., and Bai, X. (2014). Effects of exogenous nitric oxide on photosynthesis, antioxidative ability, and mineral element contents of perennial ryegrass under copper stress. J. Plant Interact. 9, 402-411. doi: 10.1080/17429145.2013.845917

Eisses, J. F., and Kaplan, J. H. (2002). Molecular characterization of hCTR1, the human copper uptake protein. J. Biol. Chem. 277, 29162-29171. doi: 10.1074/ jbc.M203652200

Emamverdian, A., Ding, Y., Mokhberdoran, F., and Xie, Y. (2015). Heavy metal stress and some mechanisms of plant defense response. Sci. World J. 2015:756120. doi: 10.1155/2015/756120

Fan, H., Guo, S., Jiao, Y., Zhang, R., and Li, J. (2007). Effects of exogenous nitric oxide on growth, active oxygen species metabolism, and photosynthetic characteristics in cucumber seedlings under $\mathrm{NaCl}$ stress. Front. Agric. Sci. China 1, 308-314. doi: 10.1007/s11703-007-0052-5

Fancy, N. N., Bahlmann, A. K., and Loake, G. J. (2017). Nitric oxide function in plant abiotic stress. Plant Cell Environ. 40, 462-472. doi: 10.1111/pce.12707

Fatma, M., Masood, A., Per, T. S., and Khan, N. A. (2016a). Nitric oxide alleviates salt stress inhibited photosynthetic performance by interacting with sulfur assimilation in mustard. Front. Plant Sci. 7:521. doi: 10.3389/fpls.2016.00521

Fatma, M., Masood, A., Per, T. S., Rasheed, F., and Khan, N. A. (2016b). Interplay between nitric oxide and sulfur assimilation in salt tolerance in plants. Crop J. 4, 153-161. doi: 10.1016/j.cj.2016.01.009

Fazzari, M., Trostchansky, A., Schopfer, F. J., Salvatore, S. R., Sánchez-Calvo, B., Vitturi, D., et al. (2014). Olives and olive oil are sources of electrophilic fatty acid nitroalkenes. PLoS One 9:e84884. doi: 10.1371/journal.pone.0084884

Feigl, G., Kumar, D., Lehotai, N., Petõ, A., Molnár, Á., Rácz, É., et al. (2015). Comparing the effects of excess copper in the leaves of Brassica juncea (L.
Czern) and Brassica napus (L.) seedlings: growth inhibition, oxidative stress and photosynthetic damage. Acta Biol. Hung. 66, 205-221. doi: 10.1556/018. 66.2015.2.7

Feigl, G., Kumar, D., Lehotai, N., Tugyi, N., Molnár, Á., Ördög, A., et al. (2013). Physiological and morphological responses of the root system of Indian mustard (Brassica juncea L. Czern.) and rapeseed (Brassica napus L.) to copper stress. Ecotoxicol. Environ. Saf. 94, 179-189. doi: 10.1016/j.ecoenv.2013. 04.029

Feng, H., Zhang, Q., Wang, Q., Wang, X., Liu, J., Li, M., et al. (2013). Target of tae-miR408, a chemocyanin-like protein gene (TaCLP1), plays positive roles in wheat response to high-salinity, heavy cupric stress and stripe rust. Plant Mol. Biol. 83, 433-443. doi: 10.1007/s11103-013-0101-9

Fernández-Marcos, M., Sanz, L., Lewis, D. R., Muday, G. K., and Lorenzo, O. (2011). Nitric oxide causes root apical meristem defects and growth inhibition while reducing PIN-FORMED 1 (PIN1)-dependent acropetal auxin transport. Proc. Natl. Acad. Sci. U.S.A. 108, 18506-18511. doi: 10.1073/pnas.11086 44108

Fidalgo, F., Azenha, M., Silva, A. F., de Sousa, A., Santiago, A., Ferraz, P., et al. (2013). Copper-induced stress in Solanum nigrum L. and antioxidant defense system responses. Food Energy Sec. 2, 70-80. doi: 10.1002/fes3.20

Filippou, P., Antoniou, C., and Fotopoulos, V. (2013). The nitric oxide donor sodium nitroprusside regulates polyamine and proline metabolism in leaves of Medicago truncatula plants. Free Radic. Biol. Med. 56, 172-183. doi: 10.1016/j. freeradbiomed.2012.09.037

Gang, A., Vyas, A., and Vyas, H. (2013). Toxic effect of heavy metals on germination and seedling growth of wheat. J. Environ. Res. Dev. 8, 206-213. doi: 10.4103/0976-9668.116964

Garcia-Molina, A., Andrés-Colás, N., Perea-García, A., Neumann, U., Dodani, S. C., Huijser, P., et al. (2013). The Arabidopsis COPT6 transport protein functions in copper distribution under copper-deficient conditions. Plant Cell Physiol. 54, 1378-1390. doi: 10.1016/j.ecoenv.2013.04.029

Gonzalez-Mendoza, D., Escoboza-Garcia, F., Santamaria, J. M., and ZapataPerez, O. (2013). Copper stress on photosynthesis of black mangle (Avicennia germinans). An. Acad. Bras. Ciênc. 85, 665-670. doi: 10.1590/S000137652013000200013

Gouvea, C., Souza, J., Magalhaes, A., and Martins, I. (1997). NO•-releasing substances that induce growth elongation in maize root segments. Plant Growth Regul. 21, 183-187. doi: 10.1023/A:1005837012203

Hasanuzzaman, M., Oku, H., Nahar, K., Bhuyan, M. B., Al Mahmud, J., Baluska, F., et al. (2018). Nitric oxide-induced salt stress tolerance in plants: ROS metabolism, signaling, and molecular interactions. Plant Biotechnol. Rep. 12, 77-92. doi: 10.1007/s11816-018-0480-0

Havlin, J. L., Beaton, J. D., Tisdale, S. L., and Nelson, W. L. (1999). Soil Fertility and Fertilizers-an Introduction to Nutrient Management, 6th Edn. Upper Saddle River, NJ: Prentice Hall.

Hu, K. D., Hu, L.-Y., Li, Y. H., Zhang, F. Q., and Zhang, H. (2007). Protective roles of nitric oxide on germination and antioxidant metabolism in wheat seeds under copper stress. Plant Growth Regul. 53, 173-183. doi: 10.1007/s10725-0079216-9

Hu, Y. (2016). Early generation of nitric oxide contributes to copper tolerance through reducing oxidative stress and cell death in hulless barley roots. J. Plant Res. 129, 963-978. doi: 10.1007/s10265-016-0841-0

$\mathrm{Hu}$, Y., You, J., and Liang, X. (2015). Nitrate reductase-mediated nitric oxide production is involved in copper tolerance in shoots of hulless barley. Plant Cell Rep. 34, 367-379. doi: 10.1007/s00299-014-1715-3

Huffman, D. L., and O'Halloran, T. V. (2001). Function, structure, and mechanism of intracellular copper trafficking proteins. Annu. Rev. Biochem. 70, 677-701. doi: 10.1146/annurev.biochem.70.1.677

Ivanova, E., Kholodova, V., and Kuznetsov, V. V. (2010). Biological effects of high copper and zinc concentrations and their interaction in rapeseed plants. Russ. J. Plant Physiol. 57, 806-814. doi: 10.1134/\$1021443710060099

Jahan, B., Tabish Rehman, M., Alajmi, M. F., and Khan, N. A. (2020). Treatment of nitric oxide supplemented with nitrogen and sulfur regulates photosynthetic performance and stomatal behavior in mustard under salt stress. Physiol. Plant. 168, 490-510. doi: 10.1111/ppl.13056

Jhanji, S., Setia, R., Kaur, N., Kaur, P., and Setia, N. (2012). Role of nitric oxide in cadmium-induced stress on growth, photosynthetic components and yield of Brassica napus L. J. Environ. Biol. 33, 1027-1032. 
Jiao, C., Yang, R., Zhou, Y., and Gu, Z. (2016). Nitric oxide mediates isoflavone accumulation and the antioxidant system enhancement in soybean sprouts. Food Chem. 204, 373-380. doi: 10.1016/j.foodchem.2016.02.147

Jung, H. I., Gayomba, S. R., Rutzke, M. A., Craft, E., Kochian, L. V., and Vatamaniuk, O. K. (2012). COPT6 is a plasma membrane transporter that functions in copper homeostasis in Arabidopsis and is a novel target of SQUAMOSA promoter-binding protein-like 7. J. Biol. Chem. 287, 3325233267. doi: 10.1074/jbc.M112.397810

Kampfenkel, K., Kushnir, S., Babiychuk, E., Inzé, D., and Van Montagu, M. (1995). Molecular characterization of a putative Arabidopsis thaliana copper transporter and its yeast homologue. J. Biol. Chem. 270, 28479-28486. doi: 10.1074/jbc.270.47.28479

Kato, N., and Esaka, M. (1999). Changes in ascorbate oxidase gene expression and ascorbate levels in cell division and cell elongation in tobacco cells. Physiol. Plant 105, 321-329. doi: 10.1034/j.1399-3054.1999.105218.x

Kaur, G., and Asthir, B. J. B. P. (2015). Proline: a key player in plant abiotic stress tolerance. Biol. Plant 59, 609-619. doi: 10.1007/s10535-015-0549-3

Kaur, R., and Nayyar, H. (2014). "Ascorbic acid: a potent defender against environmental stresses," in Oxidative Damage to Plants: Antioxidant Networks and Signaling, ed. P. Ahmad (Amsterdam: Academic Press), 235-287. doi: 10.1016/B978-0-12-799963-0.00008-3

Kerk, N. M., and Feldman, N. (1995). A biochemical model for the initiation and maintenance of the quiescent center: implications for organization of root meristems. Development 121, 2825-2833.

Keutgen, A. J., and Pawelzik, E. (2008). Quality and nutritional value of strawberry fruit under long term salt stress. Food Chem. 107, 1413-1420. doi: 10.1016/j. foodchem.2007.09.071

Khairy, A. I. H., Oh, M. J., Lee, S. M., and Roh, K. S. (2016). Nitric oxide overcomes $\mathrm{Cd}$ and $\mathrm{Cu}$ toxicity in in vitro-grown tobacco plants through increasing contents and activities of rubisco and rubisco activase. Biochim. Open 2, 41-51. doi: 10.1016/j.biopen.2016.02.002

Khan, M. I. R., Nazir, F., Asgher, M., Per, T. S., and Khan, N. A. (2015). Selenium and sulfur influence ethylene formation and alleviate cadmiuminduced oxidative stress by improving proline and glutathione production in wheat. J. Plant Physiol. 173, 9-18. doi: 10.1016/j.jplph.2014.09.011

Khan, N. A., Asgher, M., Per, T. S., Masood, A., Fatma, M., and Khan, M. (2016). Ethylene potentiates sulfur-mediated reversal of cadmium inhibited photosynthetic responses in mustard. Front. Plant Sci. 7:1628. doi: 10.3389/fpls. 2016.01628

Khan, N. A., Nazar, R., Iqbal, N., and Anjum, N. A. (2012). Phytohormones and Abiotic Stress Tolerance in Plants. Heidelberg: Springer. doi: 10.1007/978-3642-25829-9

Kliebenstein, D. J., Monde, R. A., and Last, R. L. (1998). Superoxide dismutase in Arabidopsis: an eclectic enzyme family with disparate regulation and protein localization. Plant Physiol. 118, 637-650. doi: 10.1104/pp.118.2.637

Klomp, A. E., Juijn, J. A., Berger, R., and Klomp, L. W. (2003). The N-terminus of the human copper transporter 1 (hCTR1) is localized extracellularly, and interacts with itself. Biochem. J. 370, 881-889. doi: 10.1042/bj2002 1128

Kolbert, Z., Petõ, A., Lehotai, N., Feigl, G., and Erdei, L. (2012). Long-term copper $\left(\mathrm{Cu}^{2+}\right)$ exposure impacts on auxin, nitric oxide (NO) metabolism and morphology of Arabidopsis thaliana L. Plant Growth Regul. 68, 151-159. doi: 10.1007/s10725-012-9701-7

Kolbert, Z., Petõ, A., Lehotai, N., Feigl, G., and Erdei, L. (2015). Copper sensitivity of nialnia2noa1-2 mutant is associated with its low nitric oxide (NO) level. Plant Growth Regul. 77, 255-263. doi: 10.1007/s10725-015-0059-5

Kumar Singh, A., Sharma, L., and Mallick, N. (2004). Antioxidative role of nitric oxide on copper toxicity to a chlorophycean alga, Chlorella. Ecotoxicol. Environ. Saf. 59, 223-227. doi: 10.1016/j.ecoenv.2003.10.009

Küpper, H., Götz, B., Mijovilovich, A., Küpper, F. C., and Meyer-Klaucke, W. (2009). Complexation and toxicity of copper in higher plants. I. Characterization of copper accumulation, speciation, and toxicity in Crassula helmsii as a new copper accumulator. Plant Physiol. 151, 702-714. doi: 10.1104/ pp.109.139717

Kushwaha, B. K., Singh, S., Tripathi, D. K., Sharma, S., Prasad, S. M., Chauhan, D. K., et al. (2019). New adventitious root formation and primary root biomass accumulation are regulated by nitric oxide and reactive oxygen species in rice seedlings under arsenate stress. J. Hazard. Mater. 361, 134-140. doi: 10.1016/j. jhazmat.2018.08.035

Laspina, N., Groppa, M., Tomaro, M., and Benavides, M. (2005). Nitric oxide protects sunflower leaves against Cd-induced oxidative stress. Plant Sci. 169, 323-330. doi: 10.1016/j.plantsci.2005.02.007

Lequeux, H., Hermans, C., Lutts, S., and Verbruggen, N. (2010). Response to copper excess in Arabidopsis thaliana: impact on the root system architecture, hormone distribution, lignin accumulation and mineral profile. Plant Physiol. Biochem. 48, 673-682. doi: 10.1016/j.plaphy.2010.05.005

Leterrier, M., Airaki, M., Palma, J. M., Chaki, M., Barroso, J. B., and Corpas, F. J. (2012). Arsenic triggers the nitric oxide (NO) and S-nitrosoglutathione (GSNO) metabolism in Arabidopsis. Environ. Pollut. 166, 136-143. doi: 10.1016/j.envpol. 2012.03.012

Li, Q., Huang, W., Xiong, C., and Zhao, J. (2018). Transcriptome analysis reveals the role of nitric oxide in Pleurotus eryngii responses to $\mathrm{Cd} 2+$ stress. Chemosphere 201, 294-302. doi: 10.1016/j.chemosphere.2018.03.011

Lin, C. C., Chen, L. M., and Liu, Z. H. (2005). Rapid effect of copper on lignin biosynthesis in soybean roots. Plant Sci. 168, 855-861. doi: 10.1016/j.plantsci. 2004.10.023

Liu, S., Yang, R., Pan, Y., Ren, B., Chen, Q., Li, X., et al. (2016). Beneficial behavior of nitric oxide in copper-treated medicinal plants. J. Hazard. Mater. 314, 140-154. doi: 10.1016/j.jhazmat.2016.04.042

Llagostera, I., Cervantes, D., Sanmartí, N., Romero, J., and Pérez, M. (2016). Effects of copper exposure on photosynthesis and growth of the seagrass Cymodocea nodosa: an experimental assessment. Bull. Environ. Contam. Toxicol. 97, 374379. doi: 10.1007/s00128-016-1863-y

Lombardo, M. C., Graziano, M., Polacco, J. C., and Lamattina, L. (2006). Nitric oxide functions as a positive regulator of root hair development. Plant Signal. Behav. 1, 28-33. doi: 10.4161/psb.1.1.2398

López-Bucio, J., Cruz-Ramırez, A., and Herrera-Estrella, L. (2003). The role of nutrient availability in regulating root architecture. Curr. Opin. Plant Biol. 6, 280-287. doi: 10.1016/S1369-5266(03)00035-9

Lum, H. K., Lee, C. H., Butt, Y. K. C., and Lo, S. C. L. (2005). Sodium nitroprusside affects the level of photosynthetic enzymes and glucose metabolism in Phaseolus aureus (mung bean). Nitric Oxide 12, 220-230. doi: 10.1016/j.niox.2005. 03.002

Maksymiec, W., and Baszyński, T. (1996). Different susceptibility of runner bean plants to excess copper as a function of the growth stages of primary leaves. J. Plant Physiol. 149, 217-221. doi: 10.1016/S0176-1617(96)80198-2

Maksymiec, W., Russa, R., Urbanik-Sypniewska, T., and Baszyñski, T. (1994). Effect of excess $\mathrm{Cu}$ on the photosynthetic apparatus of runner bean leaves treated at two different growth stages. Physiol. Plant. 91, 715-721. doi: 10.1111/ j.1399-3054.1994.tb03010.x

Maksymiec, W., Wojcik, M., and Krupa, Z. (2007). Variation in oxidative stress and photochemical activity in Arabidopsis thaliana leaves subjected to cadmium and excess copper in the presence or absence of jasmonate and ascorbate. Chemosphere 66, 421-427. doi: 10.1016/j.chemosphere.2006.06.025

Marastoni, L., Sandri, M., Pii, Y., Valentinuzzi, F., Brunetto, G., Cesco, S., et al. (2019a). Synergism and antagonisms between nutrients induced by copper toxicity in grapevine rootstocks: monocropping vs. intercropping. Chemosphere 214, 563-578. doi: 10.1016/j.chemosphere.2018.09.127

Marastoni, L., Sandri, M., Pii, Y., Valentinuzzi, F., Cesco, S., and Mimmo, T. (2019b). Morphological root responses and molecular regulation of cation transporters are differently affected by copper toxicity and cropping system depending on the grapevine rootstock genotype. Front. Plant Sci. 10:946. doi: $10.3389 /$ fpls.2019.00946

Marques, D. M., Júnior, V. V., Da Silva, A. B., Mantovani, J. R., Magalhães, P. C., and De Souza, T. C. (2018). Copper toxicity on photosynthetic responses and root morphology of Hymenaea courbaril L.(Caesalpinioideae). Water Air Soil Pollut. 229:138. doi: 10.1007/s11270-018-3769-2

Marschner, H. (1995). Mineral Nutrition of Higher Plants, 2nd Edn. London: Academic Press.

Masood, A., Iqbal, N., and Khan, N. A. (2012). Role of ethylene in alleviation of cadmium-induced photosynthetic capacity inhibition by sulphur in mustard. Plant Cell Environ. 35, 524-533. doi: 10.1111/j.1365-3040.2011.02432.x

Masood, A., Khan, M. I. R., Fatma, M., Asgher, M., Per, T. S., and Khan, N. A. (2016). Involvement of ethylene in gibberellic acid-induced sulfur assimilation, 
photosynthetic responses, and alleviation of cadmium stress in mustard. Plant Physiol. Biochem. 104, 1-10. doi: 10.1016/j.plaphy.2016.03.017

Mata-Pérez, C., Sánchez-Calvo, B., Padilla, M. N., Begara-Morales, J. C., Luque, F., Melguizo, M., et al. (2016). Nitro-fatty acids in plant signaling: nitro-linolenic acid induces the molecular chaperone network in Arabidopsis. Plant Physiol. 170, 686-701. doi: 10.1104/pp.15.01671

Mateos-Naranjo, E., Andrades-Moreno, L., Cambrollé, J., and Perez-Martin, A. (2013). Assessing the effect of copper on growth, copper accumulation and physiological responses of grazing species Atriplex halimus: ecotoxicological implications. Ecotoxicol. Environ. Saf. 90, 136-142. doi: 10.1016/j.ecoenv.2010. 12.020

Maunoury, N., and Vaucheret, H. (2011). AGO1 and AGO2 act redundantly in miR408-mediated Plantacyanin regulation. PLoS One 6:e28729. doi: 10.1371/ journal.pone.0028729

McCaig, B. C., Meagher, R. B., and Dean, J. F. (2005). Gene structure and molecular analysis of the laccase-like multicopper oxidase (LMCO) gene family in Arabidopsis thaliana. Planta 221, 619-636. doi: 10.1007/s00425-004-1472-6

Mench, M., and Bes, C. (2009). Assessment of ecotoxicity of topsoils from a wood treatment site. Pedosphere 19, 143-155. doi: 10.1016/S1002-0160(09)60104- 1

Meng, H., Hua, S., Shamsi, I. H., Jilani, G., Li, Y., and Jiang, L. (2009). Cadmiuminduced stress on the seed germination and seedling growth of Brassica napus L., and its alleviation through exogenous plant growth regulators. Plant Growth Regul. 58, 47-59. doi: 10.1007/s10725-008-9351-y

Millar, A. H., Eubel, H., Jänsch, L., Kruft, V., Heazlewood, J. L., and Braun, H. P. (2004). Mitochondrial cytochrome c oxidase and succinate dehydrogenase complexes contain plant specific subunits. Plant Mol. Biol. 56, 77-90. doi: 10.1007/s11103-004-2316-2

Mocquot, B., Vangronsveld, J., Clijsters, H., and Mench, M. (1996). Copper toxicity in young maize (Zea mays L.) plants: effects on growth, mineral and chlorophyll contents, and enzyme activities. Plant Soil 182, 287-300. doi: 10. 1007/BF00029060

Mostofa, M. G., Seraj, Z. I., and Fujita, M. (2014). Exogenous sodium nitroprusside and glutathione alleviate copper toxicity by reducing copper uptake and oxidative damage in rice (Oryza sativa L.) seedlings. Protoplasma 251, 13731386. doi: 10.1007/s00709-014-0639-7

Muccifora, S., and Bellani, L. M. (2013). Effects of copper on germination and reserve mobilization in Vicia sativa L. seeds. Environ. Pollut. 179, 68-74. doi: 10.1016/j.envpol.2013.03.061

Murgia, I., De Pinto, M. C., Delledonne, M., Soave, C., and De Gara, L. (2004). Comparative effects of various nitric oxide donors on ferritin regulation, programmed cell death, and cell redox state in plant cells. J. Plant Physiol. 161, 777-783. doi: 10.1016/j.jplph.2003.12.004

Mwamba, T. M., Li, L., Gill, R. A., Islam, F., Nawaz, A., Ali, B., et al. (2016). Differential subcellular distribution and chemical forms of cadmium and copper in Brassica napus. Ecotoxicol. Environ. Saf. 134, 239-249. doi: 10.1016/j. ecoenv.2016.08.021

Nagajyoti, P. C., Lee, K. D., and Sreekanth, T. (2010). Heavy metals, occurrence and toxicity for plants: a review. Environ. Chem. Lett. 8, 199-216. doi: 10.1007/ s10311-010-0297-8

Nair, P. M., and Chung, I. M. (2015). Study on the correlation between copper oxide nanoparticles induced growth suppression and enhanced lignification in Indian mustard (Brassica juncea L.). Ecotoxicol. Environ. Saf. 113, 302-313. doi: 10.1016/j.ecoenv.2014.12.013

Nazir, F., Hussain, A., and Fariduddin, Q. (2019). Hydrogen peroxide modulate photosynthesis and antioxidant systems in tomato (Solanum lycopersicum L.) plants under copper stress. Chemosphere 230, 544-558. doi: 10.1016/j. chemosphere.2019.05.001

Nelson, N. (1999). Metal ion transporters and homeostasis. EMBO J. 18, 43614371. doi: 10.1093/emboj/18.16.4361

Nevitt, T., Öhrvik, H., and Thiele, D. J. (2012). Charting the travels of copper in eukaryotes from yeast to mammals. Biochim. Biophys. Acta 1823, 1580-1593. doi: 10.1016/j.bbamcr.2012.02.011

O'Halloran, T. V., and Culotta, V. C. (2000). Metallochaperones, an intracellular shuttle service for metal ions. J. Biol. Chem. 275, 25057-25060. doi: 10.1074/jbc. R000006200

O’Lexy, R., Kasai, K., Clark, N., Fujiwara, T., Sozzani, R., and Gallagher, K. L. (2018). Exposure to heavy metal stress triggers changes in plasmodesmatal permeability via deposition and breakdown of callose. J. Exp. Bot. 69, 37153728. doi: 10.1093/jxb/ery171

Ördög, A., Wodala, B., Rózsavölgyi, T., Tari, I., and Horváth, F. (2013). Regulation of guard cell photosynthetic electron transport by nitric oxide. J. Exp. Bot. 64, 1357-1366. doi: 10.1093/jxb/ers397

Ouzounidou, G., Ėiamporová, M., Moustakas, M., and Karataglis, S. (1995). Responses of maize (Zea mays L.) plants to copper stress-I. Growth, mineral content and ultrastructure of roots. Environ. Exp. Bot. 35, 167-176.

Ouzounidou, G., Ilias, I., Tranopoulou, H., and Karataglis, S. (1998). Amelioration of copper toxicity by iron on spinach physiology. J. Plant. Nutr. 21, 2089-2101. doi: 10.1080/01904169809365546

Oz, M. T., Eyidogan, F., Yucel, M., and Öktem, H. A. (2015). "Functional role of nitric oxide under abiotic stress conditions," in Nitric Oxide Action in Abiotic Stress Responses in Plants, eds M. N. Khan, M. Mobin, F. Mohammad, and F. J. Corpas (Cham: Springer), 21-41. doi: 10.1007/978-3-319-17804-2_2

Pagnussat, G. C., Lanteri, M. L., Lombardo, M. C., and Lamattina, L. (2004). Nitric oxide mediates the indole acetic acid induction activation of a mitogenactivated protein kinase cascade involved in adventitious root development. Plant Physiol. 135, 279-286. doi: 10.1104/pp.103.038554

Per, T. S., Khan, N. A., Masood, A., and Fatma, M. (2016). Methyl jasmonate alleviates cadmium-induced photosynthetic damages through increased S-assimilation and glutathione production in mustard. Front. Plant Sci. 7:1933. doi: $10.3389 /$ fpls.2016.01933

Per, T. S., Khan, N. A., Reddy, P. S., Masood, A., Hasanuzzaman, M., Khan, M. I. R., et al. (2017a). Approaches in modulating proline metabolism in plants for salt and drought stress tolerance: phytohormones, mineral nutrients and transgenics. Plant Physiol. Biochem. 115, 126-140. doi: 10.1016/j.plaphy.2017. 03.018

Per, T. S., Masood, A., and Khan, N. A. (2017b). Nitric oxide improves S-assimilation and GSH production to prevent inhibitory effects of cadmium stress on photosynthesis in mustard (Brassica juncea L.). Nitric Oxide 68, 111-124. doi: 10.1016/j.niox.2016.12.012

Perea-García, A., Garcia-Molina, A., Andrés-Colás, N., Vera-Sirera, F., PérezAmador, M. A., Puig, S., et al. (2013). Arabidopsis copper transport protein COPT2 participates in the cross talk between iron deficiency responses and low-phosphate signaling. Plant Physiol. 162, 180-194. doi: 10.1104/pp.112. 212407

Petó, A., Lehotai, N., Lozano-Juste, J., León, J., Tari, I., Erdei, L., et al. (2011). Involvement of nitric oxide and auxin in signal transduction of copper-induced morphological responses in Arabidopsis seedlings. Ann. Bot. 108, 449-457. doi: $10.1093 / \mathrm{aob} / \mathrm{mcr} 176$

Piotrowska-Niczyporuk, A., Bajguz, A., Zambrzycka, E., and GodlewskaŻyłkiewicz, B. (2012). Phytohormones as regulators of heavy metal biosorption and toxicity in green alga Chlorella vulgaris (Chlorophyceae). Plant Physiol. Biochem. 52, 52-65. doi: 10.1016/j.plaphy.2011.11.009

Potters, G., Pasternak, T. P., Guisez, Y., and Jansen, M. A. (2009). Different stresses, similar morphogenic responses: integrating a plethora of pathways. Plant Cell Environ. 32, 158-169. doi: 10.1111/j.1365-3040.2008.01908.x

Prado, A. M., Porterfield, D. M., and Feijó, J. A. (2004). Nitric oxide is involved in growth regulation and re-orientation of pollen tubes. Development 131, 2707-2714. doi: 10.1242/dev.01153

Printz, B., Lutts, S., Hausman, J. F., and Sergeant, K. (2016). Copper trafficking in plants and its implication on cell wall dynamics. Front. Plant Sci. 7:601. doi: $10.3389 /$ fpls.2016.00601

Puig, S. (2014). Function and regulation of the plant COPT family of high-affinity copper transport proteins. Adv. Bot. 2014:476917. doi: 10.1155/2014/476917

Puig, S., Andrés-Colás, N., García-Molina, A., and Penarrubia, L. (2007). Copper and iron homeostasis in Arabidopsis: responses to metal deficiencies, interactions and biotechnological applications. Plant Cell Environ. 30, 271-290. doi: 10.1111/j.1365-3040.2007.01642.x

Puig, S., and Thiele, D. J. (2002). Molecular mechanisms of copper uptake and distribution. Curr. Opin. Chem. Biol. 6, 171-180. doi: 10.1016/S1367-5931(02) 00298-3

Quartacci, M. F., Pinzino, C., Sgherri, C. L., Dalla Vecchia, F., and Navari-Izzo, F. (2000). Growth in excess copper induces changes in the lipid composition and fluidity of PSII-enriched membranes in wheat. Physiol. Plant. 108, 87-93. doi: 10.1034/j.1399-3054.2000.108001087.x 
Raeisi, M., Asrar, Z., and Pourseyedi, S. (2009). Interaction of sodium nitroprusside and copper on some growth and physiologic parameters of garden cress (Lepidium sativum L.). Iran. J. Plant Biol. 1, 55-76.

Raven, J. A., Evans, M. C., and Korb, R. E. (1999). The role of trace metals in photosynthetic electron transport in $\mathrm{O} 2$-evolving organisms. Photosynth. Res. 60, 111-150.

Rizwan, M., Mostofa, M. G., Ahmad, M. Z., Imtiaz, M., Mehmood, S., Adeel, M., et al. (2018). Nitric oxide induces rice tolerance to excessive nickel by regulating nickel uptake, reactive oxygen species detoxification and defense-related gene expression. Chemosphere 191, 23-35. doi: 10.1016/j.chemosphere.2017. 09.068

Rodriguez, F. I., Esch, J. J., Hall, A. E., Binder, B. M., Schaller, G. E., and Bleecker, A. B. (1999). A copper cofactor for the ethylene receptor ETR1 from Arabidopsis. Science 283, 996-998. doi: 10.1126/science.283.54 04.996

Saleem, M. H., Ali, S., Irshad, S., Hussaan, M., Rizwan, M., Rana, M. S., et al. (2020). Copper uptake and accumulation, ultra-structural alteration, and bast fibre yield and quality of fibrous jute (Corchorus capsularis L.) plants grown under two different soils of China. Plants 9:404. doi: 10.3390/plants9030404

Sancenón, V., Puig, S., Mateu-Andrés, I., Dorcey, E., Thiele, D. J., and Peñarrubia, L. (2004). The Arabidopsis copper transporter COPT1 functions in root elongation and pollen development. J. Biol. Chem. 279, 15348-15355. doi: 10. 1074/jbc.M313321200

Sancenón, V., Puig, S., Mira, H., Thiele, D. J., and Peñarrubia, L. (2003). Identification of a copper transporter family in Arabidopsis thaliana. Plant Mol. Biol. 51, 577-587.

Sánchez-Calvo, B., Barroso, J. B., and Corpas, F. J. (2013). Hypothesis: nitro-fatty acids play a role in plant metabolism. Plant Sci. 199, 1-6. doi: 10.1016/j.plantsci. 2012.10.006

Sánchez-Pardo, B., Fernández-Pascual, M., and Zornoza, P. (2014). Copper microlocalisation and changes in leaf morphology, chloroplast ultrastructure and antioxidative response in white lupin and soybean grown in copper excess. J. Plant Res. 127, 119-129. doi: 10.1007/s10265-013-0583-1

Santisree, P., Adimulam, S. S., Sharma, K., Bhatnagar-Mathur, P., and Sharma, K. K. (2019). "Insights into the nitric oxide mediated stress tolerance in plants," in Plant Signaling Molecules, eds M. I. R. Khan, P. S. Reddy, A. Ferrante, and N. A. Khan (Amsterdam: Elsevier), 385-406. doi: 10.1016/B978-0-12-8164518.00024-1

Schubert, M., Petersson, U. A., Haas, B. J., Funk, C., Schröder, W. P., and Kieselbach, T. (2002). Proteome map of the chloroplast lumen of Arabidopsis thaliana. J. Biol. Chem. 277, 8354-8365. doi: 10.1074/jbc.M10857 5200

Sehar, Z., Masood, A., and Khan, N. A. (2019). Nitric oxide reverses glucosemediated photosynthetic repression in wheat (Triticum aestivum L.) under salt stress. Environ. Exp. Bot. 151, 277-289. doi: 10.1016/j.envexpbot.2019.01.010

Shams, M., Ekinci, M., Turan, M., Dursun, A., Kul, R., and Yildirim, E. (2019). Growth, nutrient uptake and enzyme activity response of Lettuce (Lactuca sativa L.) to excess copper. Environ. Sustain. 2, 67-73. doi: 10.1007/s42398-01900051-7

Sharma, P., Sirhindi, G., Singh, A. K., Kaur, H., and Mushtaq, R. (2017). Consequences of copper treatment on pigeon pea photosynthesis, osmolytes and antioxidants defense. Physiol. Mol. Biol. Plant 23, 809-816. doi: 10.1007/ s12298-017-0461-8

Shi, K., Li, X., Zhang, H., Zhang, G., Liu, Y., Zhou, Y., et al. (2015). Guard cell hydrogen peroxide and nitric oxide mediate elevated $\mathrm{CO}_{2}$-induced stomatal movement in tomato. New Phytol. 208, 342-353. doi: 10.1111/nph.13621

Shiyab, S. (2018). Phytoaccumulation of copper from irrigation water and its effect on the internal structure of lettuce. Agriculture 8:29. doi: 10.3390/ agriculture 8020029

Takahashi, M., and Morikawa, H. (2014). Nitrogen dioxide is a positive regulator of plant growth. Plant Signal. Behav. 9:e28033. doi: 10.4161/psb. 28033

Takahashi, R., Bashir, K., Ishimaru, Y., Nishizawa, N. K., and Nakanishi, H. (2012). The role of heavy-metal ATPases, HMAs, in zinc and cadmium transport in rice. Plant Signal. Behav. 7, 1605-1607. doi: 10.4161/psb.22454

Tewari, R. K., Hahn, E. J., and Paek, K. Y. (2008). Modulation of copper toxicity-induced oxidative damage by nitric oxide supply in the adventitious roots of Panax ginseng. Plant Cell Rep. 27, 171-181. doi: 10.1007/s00299-0070423-7

Thounaojam, T. C., Panda, P., Mazumdar, P., Kumar, D., Sharma, G. D., Sahoo, L., et al. (2012). Excess copper induced oxidative stress and response of antioxidants in rice. Plant Physiol. Biochem. 53, 33-39. doi: 10.1016/j.plaphy. 2012.01.006

Tian, X., and Lei, Y. (2006). Nitric oxide treatment alleviates drought stress in wheat seedlings. Biol. Plant 50, 775-778. doi: 10.1007/s10535-0060129-7

Tun, N. N., Holk, A., and Scherer, G. F. (2001). Rapid increase of NO release in plant cell cultures induced by cytokinin. FEBS Lett. 509, 174-176.

Verma, J. P., Singh, V., and Yadav, J. (2011). Effect of copper sulphate on seed germination, plant growth and peroxidase activity of mung bean (Vigna radiata). Int. J. Bot. 7, 200-204. doi: 10.3923/ijb.2011.200.204

Wang, L., Yang, L., Yang, F., Li, X., Song, Y., Wang, X., et al. (2010). Involvements of $\mathrm{H}_{2} \mathrm{O}_{2}$ and metallothionein in $\mathrm{NO}$-mediated tomato tolerance to copper toxicity. J. Plant. Physiol. 167, 1298-1306. doi: 10.1016/j.jplph.2010. 04.007

Wang, Y., Hu, M., Cui, X., Lou, Y., and Zhuge, Y. (2018). Exogenous NO mediated the detoxification pathway of tomato seedlings under different stress of $\mathrm{Cu}$ and Cd. J. Appl. Ecol. 29, 4199-4207. doi: 10.13287/j.1001-9332.2018 12.031

Weigel, M., Varotto, C., Pesaresi, P., Finazzi, G., Rappaport, F., Salamini, F., et al. (2003). Plastocyanin is indispensable for photosynthetic electron flow in Arabidopsis thaliana. J. Biol. Chem. 278, 31286-31289. doi: 10.1074/jbc. M302876200

Welch, R. M., Norvell, W. A., Schaefer, S. C., Shaff, J. E., and Kochian, L. V. (1993). Induction of iron (III) and copper (II) reduction in pea (Pisum sativum L.) roots by Fe and Cu status: Does the root-cell plasmalemma Fe (III)-chelate reductase perform a general role in regulating cation uptake? Planta 190, 555-561. doi: 10.1007/BF00224795

Williams, L. E., and Mills, R. F. (2005). P1B-ATPases-an ancient family of transition metal pumps with diverse functions in plants. Trends Plant Sci. 10, 491-502. doi: 10.1016/j.tplants.2005.08.008

Wise, R. R., and Hoober, J. K. (eds) (2007). The Structure and Function of Plastids. Berlin: Springer. doi: 10.1007/978-1-4020-4061-0

Wu, X., Zhu, X., Chen, J., Yang, S., Ding, H., and Zha, D. (2013). Nitric oxide alleviates adverse salt-induced effects by improving the photosynthetic performance and increasing the anti-oxidant capacity of eggplant (Solanum melongena L.). J. Hortic. Sci. Biotechnol. 88, 352-360. doi: 10.1080/14620316. 2013.11512976

Xiong, J., An, L., Lu, H., and Zhu, C. (2009). Exogenous nitric oxide enhances cadmium tolerance of rice by increasing pectin and hemicellulose contents in root cell wall. Planta 230, 755-765. doi: 10.1007/s00425-009. 0984-5

Yamasaki, H., Hayashi, M., Fukazawa, M., Kobayashi, Y., and Shikanai, T. (2009). SQUAMOSA promoter binding protein-like7 is a central regulator for copper homeostasis in Arabidopsis. Plant Cell 21, 347-361. doi: 10.1105/tpc.108. 060137

Yan, J., Wang, P., Wang, P., Yang, M., Lian, X., Tang, Z., et al. (2016). A lossof-function allele of OsHMA3 associated with high cadmium accumulation in shoots and grain of Japonica rice cultivars. Plant Cell Environ. 39, 1941-1954. doi: $10.1111 /$ pce. 12747

Ye, Y., Li, Z., and Xing, D. (2013). Nitric oxide promotes MPK6-mediated caspase3-like activation in cadmium-induced Arabidopsis thaliana programmed cell death. Plant Cell Environ. 36, 1-15. doi: 10.1111/j.1365-3040.2012.02 543.x

Yruela, I. (2005). Copper in plants. Braz. J. Plant Physiol. 17, 145-156. doi: 10.1590/ S1677-04202005000100012

Yu, C. C., Hung, K. T., and Kao, C. H. (2005). Nitric oxide reduces Cu toxicity and $\mathrm{Cu}$-induced $\mathrm{NH}^{4+}$ accumulation in rice leaves. J. Plant Physiol. 162, 1319-1330. doi: 10.1016/j.jplph.2005.02.003

Yuan, H. M., Xu, H. H., Liu, W. C., and Lu, Y. T. (2013). Copper regulates primary root elongation through $\mathrm{PIN} 1-$ mediated auxin redistribution. Plant Cell Physiol. 54, 766-778. doi: 10.1093/pcp/pct030

Zhang, L. P., Mehta, S. K., Liu, Z. P., and Yang, Z. M. (2008). Copper-induced proline synthesis is associated with nitric oxide generation in Chlamydomonas 
reinhardtii. Plant Cell Physiol. 49, 411-419. doi: 10.1093/pcp/pc n017

Zhang, P., Li, S., Guo, Z., and Lu, S. (2019). Nitric oxide regulates glutathione synthesis and cold tolerance in forage legumes. Environ. Exp. Bot. 167:103851. doi: 10.1016/j.envexpbot.2019.103851

Zhang, Y., Han, X., Chen, X., Jin, H., and Cui, X. (2009). Exogenous nitric oxide on antioxidative system and ATPase activities from tomato seedlings under copper stress. Sci. Hortic. 123, 217-223.

Zottini, M., Formentin, E., Scattolin, M., Carimi, F., Lo Schiavo, F., and Terzi, M. (2002). Nitric oxide affects plant mitochondrial functionality in vivo. FEBS Lett. 515, 75-78. doi: 10.1016/s0014-5793(02)02438-9
Conflict of Interest: The authors declare that the research was conducted in the absence of any commercial or financial relationships that could be construed as a potential conflict of interest.

Copyright (c) 2020 Rather, Masood, Sehar, Majid, Anjum and Khan. This is an open-access article distributed under the terms of the Creative Commons Attribution License (CC BY). The use, distribution or reproduction in other forums is permitted, provided the original author(s) and the copyright owner(s) are credited and that the original publication in this journal is cited, in accordance with accepted academic practice. No use, distribution or reproduction is permitted which does not comply with these terms. 